\title{
Recent changes and drivers of the atmospheric evaporative demand in the Canary Islands
}

\author{
Sergio M. Vicente-Serrano ${ }^{1}$, Cesar Azorin-Molina ${ }^{1}$, Arturo Sanchez-Lorenzo ${ }^{1}$, Ahmed El Kenawy ${ }^{2}$, \\ Natalia Martín-Hernández ${ }^{1}$, Marina Peña-Gallardo ${ }^{1}$, Santiago Beguería ${ }^{3}$, and Miquel Tomas-Burguera ${ }^{3}$ \\ ${ }^{1}$ Instituto Pirenaico de Ecología, Consejo Superior de Investigaciones Científicas (IPE-CSIC), Zaragoza, Spain \\ ${ }^{2}$ Department of Geography, Mansoura University, Mansoura, Egypt \\ ${ }^{3}$ Estación Experimental Aula Dei, Consejo Superior de Investigaciones Científicas (EEAD-CSIC), Zaragoza, Spain \\ Correspondence to: Sergio M. Vicente-Serrano (svicen@ipe.csic.es)
}

Received: 11 January 2016 - Published in Hydrol. Earth Syst. Sci. Discuss.: 2 March 2016

Revised: 25 July 2016 - Accepted: 7 August 2016 - Published: 23 August 2016

\begin{abstract}
We analysed recent evolution and meteorological drivers of the atmospheric evaporative demand (AED) in the Canary Islands for the period 1961-2013. We employed long and high-quality time series of meteorological variables to analyse current AED changes in this region and found that AED has increased during the investigated period. Overall, the annual $\mathrm{ET}_{\mathrm{o}}$, which was estimated by means of the FAO56 Penman-Monteith equation, increased significantly by $18.2 \mathrm{~mm} \mathrm{decade}^{-1}$ on average, with a stronger trend in summer $\left(6.7 \mathrm{~mm} \mathrm{decade}^{-1}\right)$. In this study we analysed the contribution of (i) the aerodynamic (related to the water vapour that a parcel of air can store) and (ii) radiative (related to the available energy to evaporate a quantity of water) components to the decadal variability and trends of $\mathrm{ET}_{\mathrm{o}}$. More than $90 \%$ of the observed $\mathrm{ET}_{\mathrm{o}}$ variability at the seasonal and annual scales can be associated with the variability in the aerodynamic component. The variable that recorded more significant changes in the Canary Islands was relative humidity, and among the different meteorological factors used to calculate $\mathrm{ET}_{0}$, relative humidity was the main driver of the observed $\mathrm{ET}_{\mathrm{o}}$ trends. The observed trend could have negative consequences in a number of water-depending sectors if it continues in the future.
\end{abstract}

\section{Introduction}

The atmospheric evaporative demand (AED) is one of the key variables of the hydrological cycle (Wang and Dickinson, 2012), with multiple implications for agriculture, hydrology and the environment (Allen et al., 2015). Several studies have indicated that current global warming is increasing the intensity of the hydrological cycle, mainly as a consequence of an intensification of the AED (Huntington, 2006). Sherwood and $\mathrm{Fu}$ (2014) suggested that mechanisms driving the AED over land regions could be the main driver of increasing climate aridity in world semi-arid regions under a global warming scenario.

Warming may play an important role in increasing the AED via the aerodynamic component (McVicar et al., 2012a). Following the Clausius-Clapeyron relationship, the quantity of water vapour that a given mass of air can store increases exponentially with the air temperature. Nevertheless, there are other climate variables whose temporal evolution could compensate for the increased AED induced by increasing air temperature, such as wind speed and vapour pressure deficit (McVicar et al., 2012a). In addition, the radiative component of the AED, which is related to the available solar energy that transforms a unit of liquid water into vapour, may compensate for or accentuate the increase in AED associated with warming. Wild et al. (2015) noted that solar radiation had increased over large regions since the 1980s as a consequence of changes in cloud cover and/or atmospheric aerosol concentrations.

These large number of variables interact in a non-linear manner to determine the AED (McMahon et al., 2013), so assessing recent changes in the AED and defining their determinant factors is not an easy task. For this reason, while several studies have analysed the AED at the global scale using different datasets and methods, there is no general con- 
sensus on the recent AED evolution (Sheffield et al., 2012; Matsoukas et al., 2011; Wang et al., 2012; Dai, 2013). In this context, the few existing direct AED observations, based on evaporation pans, show a decrease since the 1950s at the global scale (Peterson et al. 1995; Roderick and Farquhar, 2002, 2004), a finding that adds more uncertainty regarding the behaviour of the AED under current global warming. These issues stress the need for new studies that employ high-quality datasets to assess the time evolution of the AED at the regional scale.

There are a number of studies published in the last decade that analysed the AED evolution across different regions of the world. Some of them are based on AED estimated using empirical formulations, mostly based on air temperature data (e.g. Thornthwaite, 1948; Hargreaves and Samani, 1995). However, to adequately quantify the AED evolution it is necessary to use long time series of the meteorological variables that control its radiative and aerodynamic components (e.g. air temperature, vapour pressure deficit and wind speed). Although these variables are generally poorly measured and highly inhomogeneous over both space and time, numerous regional studies analysed the evolution of the AED by means of the robust Penman-Monteith (PM) equation using long time series of these variables. The available regional studies show quite contradictory results, where some studies showed AED negative trends, including those in China (Xu et al., 2006; Ma et al., 2012; Zhang et al., 2007; Liu et al., 2015) and northwestern India (Jhajharia et al., 2014). In contrast, other regional studies have found positive trends in AED, including those in central India (Darshana et al., 2012), Iran (Kousari and Ahani, 2012; Tabari et al., 2012), Florida (Abtew et al., 2011), continental Spain (Espadafor et al., 2011; Vicente-Serrano et al., 2014a; Azorin-Molina et al., 2015), France (Chaouche et al., 2010) and Moldova (Piticar et al., 2015).

The contrasting trends among world regions would be a consequence of the evolution of the different meteorological variables that control the AED. Specifically, some studies suggest that temporal variability and changes in the AED are related to changes in the relative humidity, mainly in semi-arid regions (Wang et al., 2012; Espadafor et al., 2011; Vicente-Serrano et al., 2014b), whereas others stress the importance of solar radiation (Roderick and Farquhar, 2002; Ambas and Baltas, 2012; Fan and Thomas, 2013) or wind speed (McVicar et al., 2012b).

Among these studies, few analysed the AED variability and trends and their possible drivers in the eastern North Atlantic region (Chaouche et al., 2010; Vicente-Serrano et al., 2014a; Azorin-Molina et al., 2015). Nevertheless, there are no studies about this issue in the subtropical areas of the North Atlantic region. In this area, there are very few meteorological stations measuring long-term series of the variables necessary to make robust calculations of the AED. This uneven distribution of meteorological observatories constrains the high interest to know the evolution of atmospheric pro- cesses in this region, where climate variability is strongly controlled by changes in the Hadley circulation (Hansen et al., 2005) that affect the position and intensity of the subtropical anticyclone belt. Knowing the evolution of AED and its main drivers in this region is highly relevant given the general climate aridity of the region and the low availability of water resources (Custodio and Cabrera, 2002). In this work we analyse the recent evolution and meteorological drivers of the AED in the Canary Islands. The main hypothesis of the study is that, in opposition to other continental temperate regions of the North Hemisphere, the warm and humid climate of the subtropical Canary Islands provides the water supply to the atmosphere needed to maintain the AED constant under the current global warming scenarios; consequently, only wind speed and solar radiation could affect the observed decadal variability and trends of the AED. Thus, the availability of long and high-quality time series of meteorological variables in the Canary Islands provides an opportunity to analyse current AED changes in the subtropical northeastern Atlantic region and the role played by different meteorological variables.

\section{Methods}

\subsection{Dataset}

We used the complete meteorological records of the Spanish National Meteorological Agency (AEMET) in the Canary Islands for the following variables at the monthly scale: maximum and minimum air temperature (308 stations), wind speed (99), sunshine duration (42) and mean relative humidity (139). The majority of the stations cover short periods or are affected by large data gaps. As the number of meteorological stations before 1961 was very little for several variables, we restricted our analysis to the period between 1961 and 2013. Specifically, only eight meteorological stations had data gaps of less than $20 \%$ of the months in all the necessary variables. As illustrated in Fig. 1, these stations are distributed between the islands of Tenerife (three stations), Gran Canaria (two), La Palma (one), Lanzarote (one) and Fuerteventura (one). Given that some series included records for a longer period (e.g. Izaña from 1933 and Santa Cruz de Tenerife from 1943), neighbouring stations with shorter temporal coverage were used to reconstruct the existing data gaps in the selected observatories, using a regression-based approach. Details of the site names, coordinates, relocations, data gaps and inhomogeneities of the selected meteorological stations can be found in Table 1 .

Then, the time series were subject to quality control and homogenization procedures. The quality control procedure was based on comparison of the rank of each data record with the average rank of the data recorded at adjacent stations (Vicente-Serrano et al., 2010). A relative homogeneity method was applied to identify possible inhomogeneities. 
Table 1. Site names, coordinates, relocations, data gaps and inhomogeneities of the selected meteorological stations in the Canary Islands.

\begin{tabular}{|c|c|c|c|c|c|c|c|c|c|c|c|c|c|c|}
\hline \multirow[t]{2}{*}{ Code } & \multirow[t]{2}{*}{ Longitude } & \multirow[t]{2}{*}{ Latitude } & \multirow[t]{2}{*}{ Name } & \multirow[t]{2}{*}{ Relocation } & \multicolumn{2}{|c|}{ Relative humidity } & \multicolumn{2}{|c|}{ Sunshine duration } & \multicolumn{2}{|c|}{ Wind speed } & \multicolumn{2}{|c|}{ Maximum temperature } & \multicolumn{2}{|c|}{ Minimum temperature } \\
\hline & & & & & Data gaps & Inhom. & Data gaps & Inhom. & Data gaps & Inhom. & Data gaps & Inhom. & Data gaps & Inhom. \\
\hline $\mathrm{C} 029 \mathrm{O}$ & -13.60 & 28.95 & Lanzarote/Airport & 1972 & $2.20 \%$ & 1998 & $0.78 \%$ & 1978-2002 & $0.47 \%$ & 1971 & $1.23 \%$ & 2004 & $1.23 \%$ & 1988 \\
\hline C139E & -17.75 & 28.61 & La Palma/Airport & 1970 & $0.94 \%$ & & $2.51 \%$ & & $0.47 \%$ & 1976 & $0.37 \%$ & & $0.37 \%$ & 1997 \\
\hline C249I & -13.85 & 28.43 & Fuerteventura/Airport & 1969 & $0.15 \%$ & 2000 & $1.25 \%$ & 1995-2005 & $0.15 \%$ & & $0.23 \%$ & 1983 & $0.23 \%$ & 1977 \\
\hline $\mathrm{C} 430 \mathrm{E}$ & -16.48 & 28.30 & Izaña & - & $1.72 \%$ & 1999 & $7.40 \%$ & 2005 & $6.91 \%$ & & $5.20 \%$ & 1985 & $5.20 \%$ & \\
\hline C447A & -16.31 & 28.46 & Los Rodeos & - & $0.31 \%$ & & $1.10 \%$ & 1966 & $0.15 \%$ & 1970 & $0.30 \%$ & 2005 & $0.30 \%$ & 2005 \\
\hline C449C & -16.25 & 28.45 & Santa Cruz de Tenerife & - & $0 \%$ & & $0.94 \%$ & & $0 \%$ & 1987 & $0 \%$ & & $0 \%$ & 1994 \\
\hline C649I & -15.38 & 27.91 & Gran Canaria/Airport & - & $0.15 \%$ & 1981-1994 & $2.67 \%$ & 1978 & $0.31 \%$ & 1972 & $0.20 \%$ & 1984 & $0.20 \%$ & 1994 \\
\hline $\mathrm{C} 659 \mathrm{P}$ & -15.41 & 28.15 & San Cristóbal & 1994 & $11 \%$ & & $1.88 \%$ & 1980 & $10.50 \%$ & 1994 & $5.30 \%$ & 1966 & $5.30 \%$ & \\
\hline
\end{tabular}

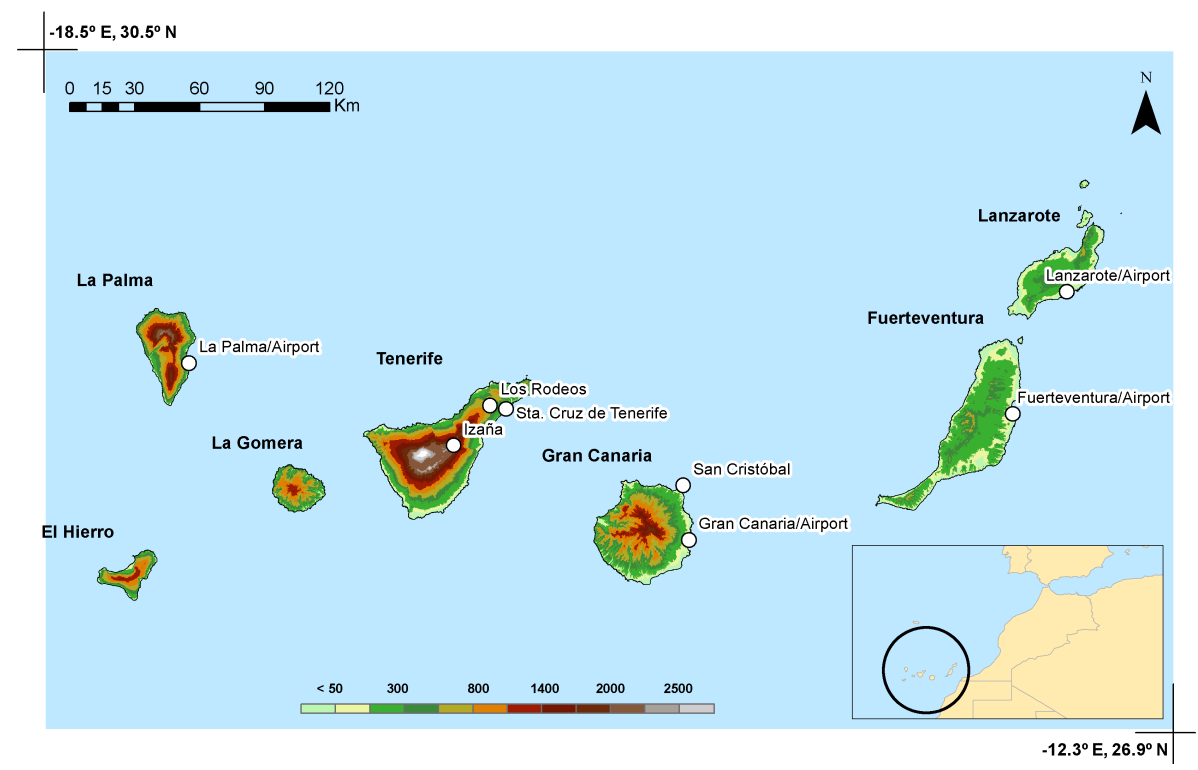

Figure 1. Location and relief of the Canary Islands and meteorological stations used in the study. Altitude is given in metres.

For this purpose, we used HOMER (HOMogenization softwarE in R), which compares each candidate series with a number of available series (Mestre et al., 2013). The method provides an estimation of break points in the time series relative to other stations, indicating high probabilities of the presence of inhomogeneities. This method was applied to the different variables and time series following Mestre et al. (2013). Finally, a single regional series for the different variables was obtained using a simple arithmetic average of data values at the available eight stations.

\subsection{Calculation of $\mathbf{E T}_{\mathrm{o}}$}

The Penman-Monteith (PM) equation is the standard technique for calculation of $\mathrm{ET}_{\mathrm{o}}$ from climatic data (Allen et al., 1998), and it is the method officially adopted (with small variations) by the International Commission for Irrigation (ICID), the Food and Agriculture Organization (FAO) of the United Nations, and the American Society of Civil Engineers (ASCE). The PM method can be used globally, and has been widely verified based on lysimeter data from diverse climatic regions (Itenfisu et al., 2000; López-Urrea et al., 2006). Allen et al. (1998) simplified the PM equation, developing the FAO-56 PM equation, and defined the reference surface as a hypothetical crop with assumed height of $0.12 \mathrm{~m}$, surface resistance of $70 \mathrm{~s} \mathrm{~m}^{-1}$ and albedo of 0.23 that had evaporation similar to that of an extended surface of green grass of uniform height that was actively growing and adequately watered. The $\mathrm{ET}_{\mathrm{O}}$ FAO-56 PM is expressed as

$\mathrm{ET}_{\mathrm{o}}=\frac{0.408 \cdot \Delta \cdot\left(R_{\mathrm{n}}-G\right)+\gamma \cdot \frac{900}{T+273} \cdot u_{2} \cdot\left(e_{\mathrm{s}}\right)-e_{\mathrm{a}}}{\Delta+\gamma \cdot\left(1+0.34 U_{2}\right)}$,

where $\mathrm{ET}_{\mathrm{o}}$ is the reference evapotranspiration $\left(\mathrm{mm} \mathrm{day}^{-1}\right)$, $R_{\mathrm{n}}$ is the net radiation at the crop surface $\left(\mathrm{MJ} \mathrm{m}^{-2} \mathrm{day}^{-1}\right), G$ is the soil heat flux density ( $\left.\mathrm{MJ} \mathrm{m}^{-2} \mathrm{day}^{-1}\right), T$ is the mean air temperature at $2 \mathrm{~m}$ height $\left({ }^{\circ} \mathrm{C}\right), u_{2}$ is the wind speed at $2 \mathrm{~m}$ height $\left(\mathrm{m} \mathrm{s}^{-1}\right), e_{\mathrm{s}}$ is the saturation vapour pressure $(\mathrm{kPa}), e_{\mathrm{a}}$ is the actual vapour pressure $(\mathrm{kPa}), e_{\mathrm{s}}-e_{\mathrm{a}}$ is the saturation vapour pressure deficit $(\mathrm{kPa}), \Delta$ is the slope of the vapour pressure curve $\left(\mathrm{kPa}^{\circ} \mathrm{C}^{-1}\right)$, and $\gamma$ is the psychrometric constant $\left(\mathrm{kPa}^{\circ} \mathrm{C}^{-1}\right)$.

The FAO-56 PM is an equation initially designed for crop monitoring and irrigation operation at daily and subdaily scales. This equation involves non-linear relationships among the variables used for calculation and averaging these 

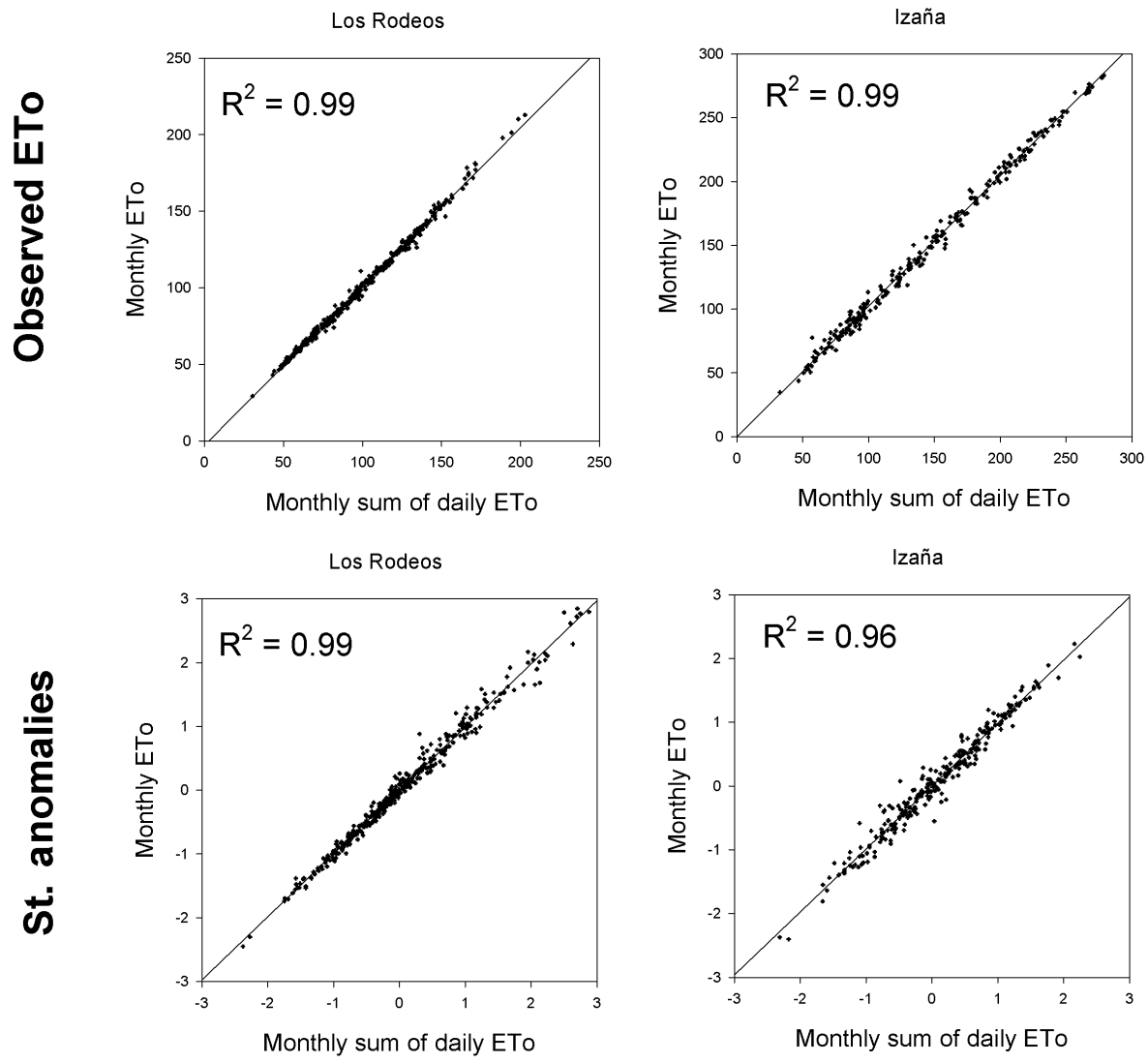

Figure 2. Comparison between the average monthly $\mathrm{ET}_{\mathrm{o}}$ obtained from daily meteorological records and the $\mathrm{ET}_{\mathrm{O}}$ directly calculated from monthly meteorological variables. Two meteorological stations in the Canary Islands are used for the period 1978-2010 (Los Rodeos and Izaña). The figure shows the relationship between monthly $\mathrm{ET}_{\mathrm{O}}$ series but also between the series of standardized anomalies in which seasonality is removed.

variables for long-term intervals could affect the reliability of the $\mathrm{ET}_{\mathrm{o}}$ estimations. Nevertheless, Allen et al. (1998) indicated that the FAO-56 PM equation can be used for daily, weekly, 10-day or monthly calculations, and several previous studies have computed the PM ET $\mathrm{E}_{\mathrm{o}}$ using monthly values for some variables (e.g. Sheffield et al., 2012; Dai, 2013). We have found that using monthly averages instead of daily records for the different variables has no relevant influence on the $\mathrm{ET}_{\mathrm{o}}$ estimations in the Canary Islands. Figure 2 shows an example using two of the available stations (Los Rodeos and Izaña) for the 1978-2010 period. The relationship between the monthly sum of the daily $\mathrm{ET}_{\mathrm{o}}$ calculations and the $\mathrm{ET}_{\mathrm{o}}$ calculation from the monthly averages justifies the equality of applying both procedures. This is observed for the $\mathrm{ET}_{\mathrm{o}}$ monthly values (including seasonality but also considering monthly standardized anomalies in which seasonality is removed). Moreover, there are other technical reasons that lead to recommending the use of monthly instead daily records to calculate $\mathrm{ET}_{\mathrm{O}}$ since testing and correcting the temporal homogeneity of the necessary variables on a daily basis is highly problematic, whereas testing and correcting homo- geneity using monthly records is reliable (e.g. Venema et al., 2012).

Therefore, the monthly $\mathrm{ET}_{\mathrm{o}}$ was calculated from data of the monthly averages of five meteorological parameters: maximum and minimum air temperature, relative humidity (which allows calculating the vapour pressure deficit), wind speed at a height of $2 \mathrm{~m}$, and daily sunshine duration (which allows estimating the net radiation). García et al. (2014) compared the capability of sunshine duration series to reconstruct long-term radiation in the observatory of Izaña (Tenerife), showing very good temporal agreement between sunshine duration and radiation, independently of the season of the year. Further details on the required equations to obtain the necessary parameters from meteorological data can be consulted in Allen et al. (1998).

We also calculated the evolution of the radiative (Eq. 2) and the aerodynamic components (Eq. 3) of the $\mathrm{ET}_{\mathrm{o}}$, as follows:

$\mathrm{ET}_{\mathrm{o}}(r)=\frac{\left[0.408 \Delta\left(R_{\mathrm{n}}-G\right)\right]}{\left[\Delta+\gamma\left(1+0.34 u_{\mathrm{s}}\right)\right]}$, 
Table 2. Seasonal and annual averages $(\mathrm{mm})$ and coefficients of variation in $\mathrm{ET}_{\mathrm{o}}$ at the eight meteorological stations, averaged over the period 1961-2013.

\begin{tabular}{|c|c|c|c|c|c|c|c|c|c|}
\hline & $\begin{array}{l}\text { Sta. Cruz } \\
\text { de Tenerife }\end{array}$ & $\begin{array}{l}\text { Gran Canaria/ } \\
\text { Airport }\end{array}$ & $\begin{array}{l}\text { Los } \\
\text { Rodeos }\end{array}$ & Izaña & Fuerteventura & La Palma & Lanzarote & $\begin{array}{l}\text { San } \\
\text { Cristóbal }\end{array}$ & $\begin{array}{l}\text { Regional } \\
\text { mean }\end{array}$ \\
\hline & \multicolumn{9}{|c|}{ Average } \\
\hline Winter & 222.0 & 181.5 & 297.5 & 250.2 & 298.1 & 251.6 & 294.5 & 217.7 & 251.6 \\
\hline Spring & 390.1 & 302.2 & 468.8 & 414.1 & 460.8 & 361.5 & 468.7 & 342.3 & 401.1 \\
\hline Summer & 512.7 & 415.5 & 612.9 & 663.8 & 560.2 & 438.7 & 586.1 & 383.0 & 521.6 \\
\hline Autumn & 311.8 & 273.9 & 401.8 & 364.5 & 384.6 & 316.4 & 393.8 & 278.8 & 340.7 \\
\hline \multirow[t]{2}{*}{ Annual } & 1435.5 & 1175.0 & 1784.4 & 1692.6 & 1702.0 & 1372.7 & 1741.0 & 1219.4 & 1515.3 \\
\hline & \multicolumn{9}{|c|}{ Coefficient of variation } \\
\hline Winter & 0.05 & 0.11 & 0.12 & 0.18 & 0.10 & 0.11 & 0.09 & 0.11 & 0.06 \\
\hline Spring & 0.04 & 0.10 & 0.07 & 0.12 & 0.08 & 0.10 & 0.06 & 0.08 & 0.05 \\
\hline Summer & 0.03 & 0.12 & 0.07 & 0.07 & 0.07 & 0.08 & 0.07 & 0.07 & 0.04 \\
\hline Autumn & 0.03 & 0.10 & 0.10 & 0.10 & 0.07 & 0.11 & 0.07 & 0.08 & 0.05 \\
\hline Annual & 0.02 & 0.07 & 0.06 & 0.07 & 0.07 & 0.08 & 0.06 & 0.05 & 0.04 \\
\hline
\end{tabular}

$\operatorname{ET}_{\mathrm{o}}(a)=\frac{\left[\gamma\left(\frac{900}{T+272}\right) u_{2}\left(e_{\mathrm{s}}-e_{\mathrm{a}}\right)\right]}{\left[\Delta+\gamma\left(1+0.34 u_{\mathrm{s}}\right)\right]}$

\subsection{Analysis}

Using the time series of $\mathrm{ET}_{\mathrm{o}}$, we determined the seasonal (winter: December-February; spring: March-May; summer: June-August; autumn: September-November) and annual $\mathrm{ET}_{\mathrm{o}}$ averages. To analyse changes in $\mathrm{ET}_{\mathrm{o}}$ we used the nonparametric Mann-Kendall statistic that measures the degree to which a trend is consistently increasing or decreasing. The Mann-Kendall statistic is advantageous compared to parametric tests as it is robust to outliers and it does not assume any underlying probability distribution of the data (Zhang et al., 2001). For these reasons, it has been widely used for trend detection in a wide range of hydrological and climatological studies (e.g. Zhang et al., 2001; El Kenawy and McCabe, 2015). Autocorrelation was considered in the trend analysis applied to the series of $\mathrm{ET}_{\mathrm{o}}$, the series of the aerodynamic and radiative components of the $\mathrm{ET}_{\mathrm{o}}$, and the series of the different climate variables (temperature, relative humidity, wind speed and sunshine duration). This was applied using the FUME R package, which performs the modified Mann-Kendall trend test, returning the corrected $p$ values after accounting for temporal pseudoreplication (Hamed and Rao, 1998; Yue and Wang, 2004). To assess the magnitude of change in $\mathrm{ET}_{\mathrm{O}}$, we used a linear regression analysis between the series of time (independent variable) and the $\mathrm{ET}_{\mathrm{O}}$ series (dependent variable). The slope of the regression indicated the amount of change (ET $\mathrm{E}_{\mathrm{o}}$ change per year), with higher slope values indicating greater change. We also calculated the trend observed in the different meteorological variables (air temperature, relative humidity, sunshine duration and wind speed) at both the seasonal and annual scales.
To get insight into the influence of changes in the different meteorological variables on $\mathrm{ET}_{\mathrm{o}}$, we related the evolution of $\mathrm{ET}_{\mathrm{o}}$ to relative humidity, maximum and minimum air temperature, wind speed, and sunshine duration by means of correlation analyses. To assess the importance of trends in the different meteorological variables on the observed trends in $\mathrm{ET}_{\mathrm{o}}$ between 1961 and 2013, we applied the PM equation while keeping one variable stationary (using the average from 1961 to 2013) each time. This approach provided five simulated series of $\mathrm{ET}_{\mathrm{o}}$, one per input variable, which could be compared to the $\mathrm{ET}_{\mathrm{O}}$ series computed with all the data to determine the isolated influence of the five variables. Significant differences between each pair of $\mathrm{ET}_{\mathrm{o}}$ series (the original one and the alternative one in which one variable was kept constant) were assessed by comparing the slopes of the linear models, with time as the independent variable. A statistical test for the equality of regression coefficients was used (Paternoster et al., 1998). The significance of the difference was assessed at a confidence interval of $95 \%(p<0.05)$.

\section{Results}

\subsection{Average ET $_{0}$ values}

Figure 3 shows a box plot with the seasonal and annual values of $\mathrm{ET}_{\mathrm{o}}$ at the different meteorological stations across the Canary Islands, which are also summarized in Table 2. There were strong seasonal differences in $\mathrm{ET}_{\mathrm{o}}$, as all different meteorological stations show their maximum values in summer and minimum in winter, albeit with strong differences among them. In winter, the highest average values were recorded in the most arid islands (i.e. Fuerteventura and Lanzarote) and at the station of Los Rodeos (northern Tenerife). In summer, the stations of Izaña and Los Rodeos showed the highest av- 

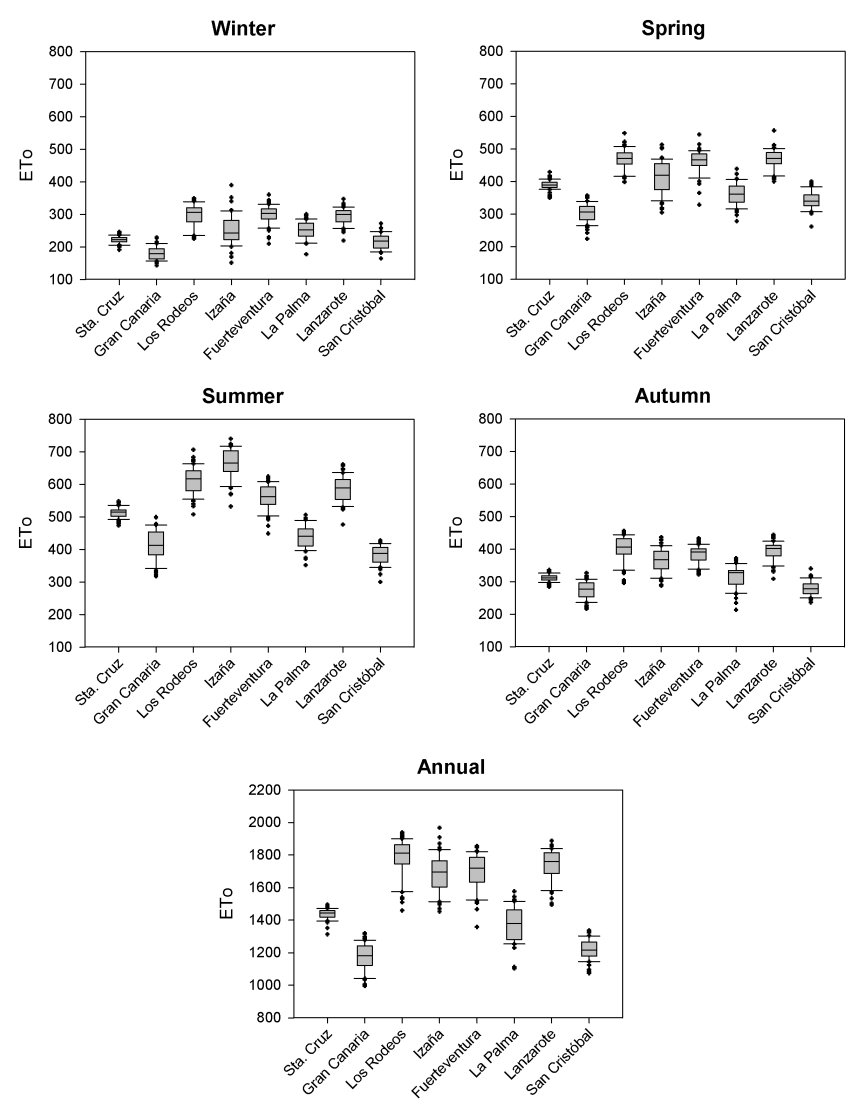

Figure 3. Box plot with the annual and seasonal $\mathrm{ET}_{\mathrm{o}}$ values at the eight meteorological stations used in this study. The vertical lines of each plotted box plot illustrate the 10th, 25th, 75th and 90th quantiles, respectively. The interquartile spread is represented by the range between the 25th and 75th quantiles. The dots show the highest and lowest values.

erage values ( 663.8 and $612.9 \mathrm{~mm}$, respectively). The lowest summer $\mathrm{ET}_{\mathrm{o}}$ averages were recorded at the stations of Gran Canaria (San Cristóbal and Gran Canaria/Airport). At the annual scale, there were very few differences in the average values between the stations of Los Rodeos, Izaña, Fuerteventura and Lanzarote, with very high $\mathrm{ET}_{\mathrm{o}}$ values ranging between 1693 and $1784 \mathrm{~mm}$ (Table 2). The observatory with the lowest $\mathrm{ET}_{\mathrm{o}}$ values is located at Gran Canaria/Airport, although the observatory of San Cristóbal (also in Gran Canaria) records the minimum values in summer. The magnitude of the differences can be quite important (up to $34 \%$ ) between the highest $\mathrm{ET}_{\mathrm{O}}$ values recorded in Los Rodeos, Izaña, Fuerteventura and Lanzarote and the lowest $\mathrm{ET}_{\mathrm{o}}$ values (Gran Canaria and San Cristóbal). In general, variability, as revealed by the coefficient of variation, was higher at the meteorological stations that recorded the highest $\mathrm{ET}_{\mathrm{o}}$ values at the annual scale, but there was no clear spatial pattern at the seasonal scale as different stations showed few differences in terms of the coefficients of variation (Table 2).
At the majority of weather stations the seasonal and annual $\mathrm{ET}_{\mathrm{O}}$ magnitude was mostly driven by the aerodynamic component. The average aerodynamic fraction was higher than the radiative fraction at the weather stations that record the highest $\mathrm{ET}_{\mathrm{O}}$ values (Los Rodeos and Izaña) in all seasons around the year (Fig. 4). At other weather stations (Santa Cruz de Tenerife and San Cristóbal), the $\mathrm{ET}_{\mathrm{o}}$ associated with the radiative component was much higher than that observed for the aerodynamic component (Table 3 ). The temporal variability in the aerodynamic component was much higher than that observed in the radiative one, regardless of the season of the year or the meteorological station.

\subsection{Long-term evolution of $\mathbf{E T}_{\mathrm{o}}$}

The regional $\mathrm{ET}_{\mathrm{o}}$ series for the whole of the Canary Islands (Fig. 5) shows a significant increase at the annual scale $\left(18.2 \mathrm{~mm} \mathrm{decade}^{-1}\right)$, which is stronger in summer $\left(6.7 \mathrm{~mm} \mathrm{decade}^{-1}\right)$ (Table 4). Nevertheless, there was a strong variability between the different meteorological stations, since most meteorological stations experimented significant increases of $\mathrm{ET}_{\mathrm{o}}$ between 1961 and 2013. The largest annual increase was recorded in Los Rodeos (34.8 mm decade ${ }^{-1}$ ), La Palma (29.8 mm decade ${ }^{-1}$ ) and Lanzarote $\left(29.7 \mathrm{~mm}^{-1}\right.$ decade $\left.^{-1}\right)$. Considering a longer period (1933-2013 for Izaña, and 1943-2013 for Santa Cruz de Tenerife), the changes are not statistically significant, although it was not possible to check the homogeneity of the climate records prior to 1961 and thus the results for the longer period must be carefully considered. For the period 1961-2013, there is no general spatial pattern in the observed changes; thus, some differences can be observed. For example, in Gran Canaria, San Cristóbal station shows a statistically non-significant negative change in $\mathrm{ET}_{\mathrm{o}}$ on the order of $-8.4 \mathrm{~mm} \mathrm{decade}^{-1}$, while there is a general significant increase of $28.4 \mathrm{~mm}^{-1 e c a d e}{ }^{-1}$ at Gran Canaria Airport.

Trends in the aerodynamic and radiative components showed clear differences among stations and for the average of the Canary Islands (Fig. 6). Main changes were recorded in the aerodynamic component. The regional series showed an increase of $16.2 \mathrm{~mm} \mathrm{decade}^{-1}$ in the aerodynamic component, but it only showed an increase of $2 \mathrm{~mm} \mathrm{decade}^{-1}$ in the radiative component (Table 5). This can be translated to an average increase in the $\mathrm{ET}_{\mathrm{O}}$ of $89 \%$ over the whole period due to changes in the aerodynamic component, and of $11 \%$ due to changes in the radiative component. However, there are spatial differences between the meteorological stations, since the aerodynamic component showed a decrease of $21 \mathrm{~mm}$ decade $^{-1}$ in San Cristóbal, compared to an increase of $44.6 \mathrm{~mm} \mathrm{decade}^{-1}$ in Los Rodeos. However, the radiative component showed lower differences among stations, with values ranging from $-9.9 \mathrm{~mm} \mathrm{decade}^{-1}$ in Los Rodeos to $12.7 \mathrm{~mm} \mathrm{decade}^{-1}$ in San Cristóbal. Nevertheless, and regardless of the observed trends, the results indicate that the interannual variability in $\mathrm{ET}_{\mathrm{o}}$ between 1961 and 2013 was 

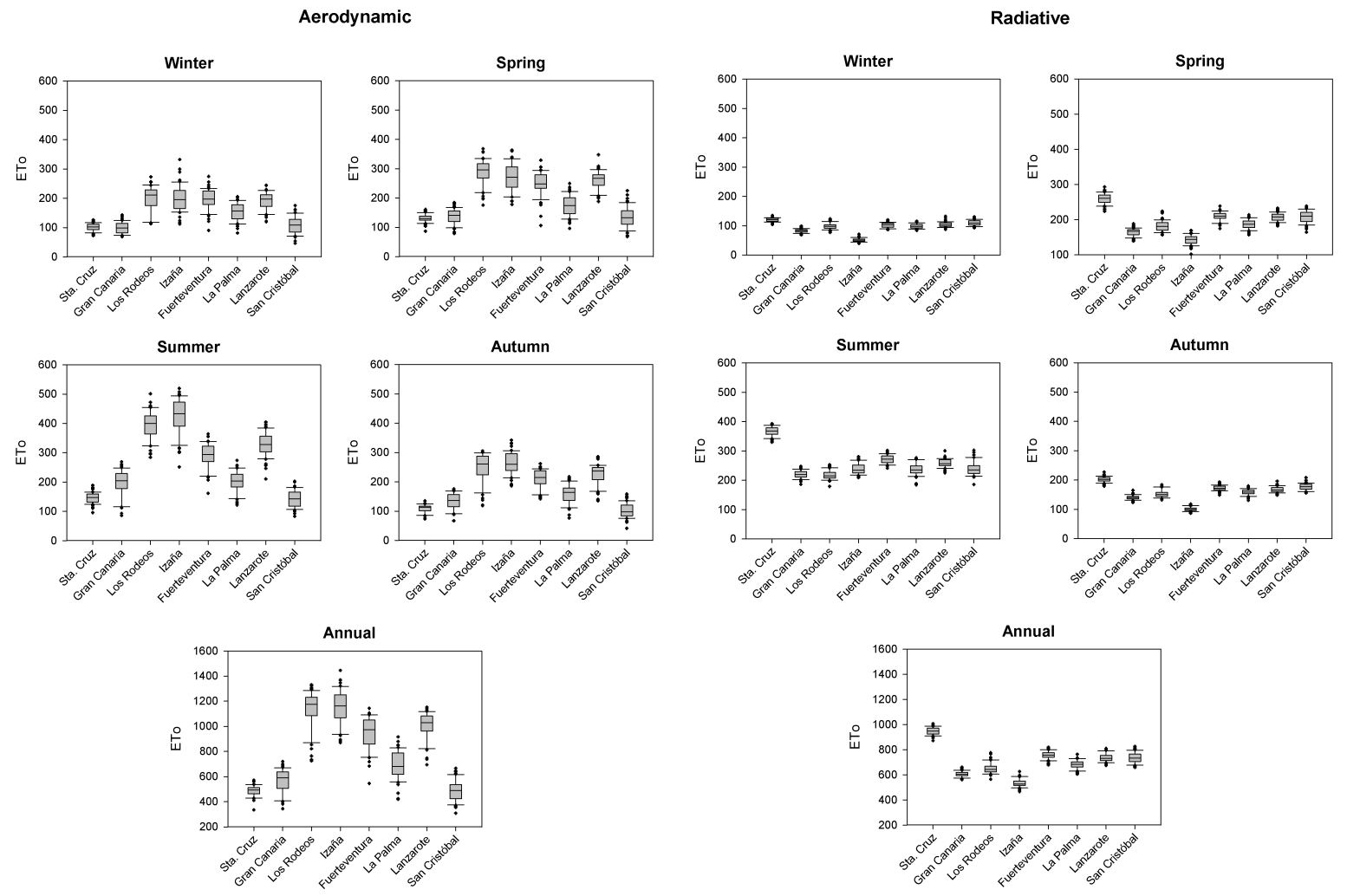

Figure 4. Box plot with the annual and seasonal aerodynamic and radiative components of $\mathrm{ET}_{\mathrm{O}}$ at the eight meteorological stations used in this study.
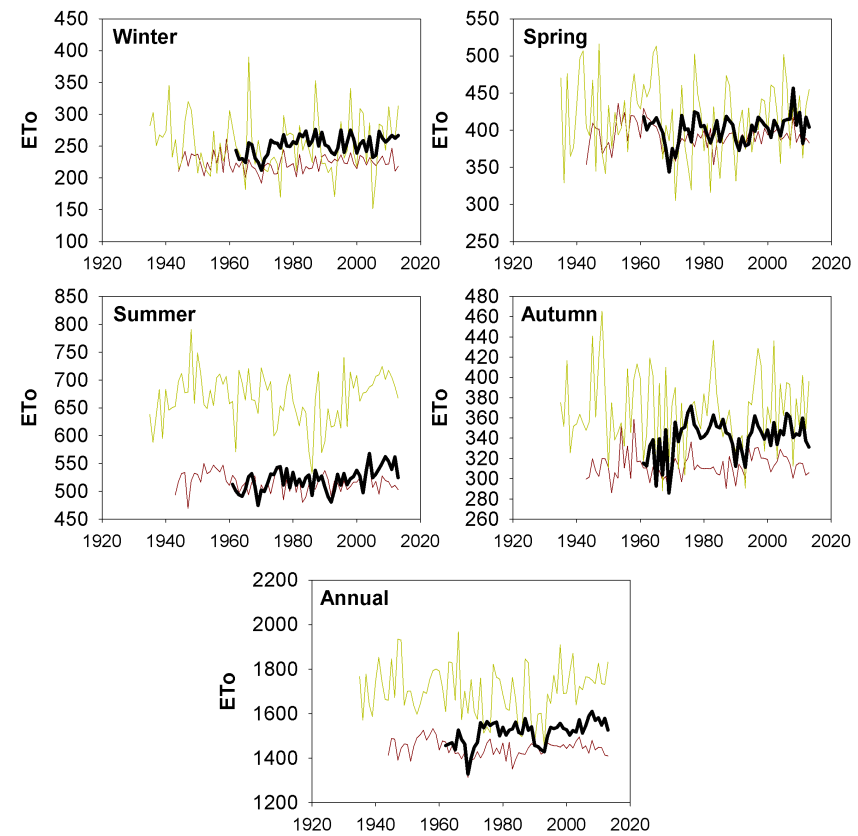

Figure 5. Evolution of seasonal and annual $\mathrm{ET}_{\mathrm{o}}$ at the two meteorological stations with longest records (Izaña, green and Santa Cruz de Tenerife, brown) and the average of the eight stations (black lines) from 1961 to 2013. mainly driven by the aerodynamic component, independently of the season or the meteorological station considered (Table 6). The temporal correlation between $\mathrm{ET}_{\mathrm{o}}$ and the aerodynamic component was statistically significant for the different meteorological stations in the seasonal and the annual series, with correlation coefficients higher than 0.95 in most cases. The correlation for the regional series was also strong and statistically significant. In contrast, the correlation coefficients calculated between $\mathrm{ET}_{\mathrm{O}}$ and the radiative component were much lower, and generally non-significant $(p<0.05)$. Los Rodeos is the unique weather station where the correlation between $\mathrm{ET}_{\mathrm{O}}$ and the radiative component was statistically significant at both the seasonal and annual scales, but showing a negative correlation. Overall, the results show that the correlation between the annual radiative component and the total annual regional series of $\mathrm{ET}_{\mathrm{o}}$ is statistically nonsignificant.

\subsection{Drivers of $\mathrm{ET}_{0}$ variability and trends}

Table 7 shows the correlation between the different meteorological variables and $\mathrm{ET}_{\mathrm{o}}$ at the seasonal and annual scales at the eight meteorological stations. Maximum and minimum air temperatures were positively correlated with $\mathrm{ET}_{\mathrm{o}}$, and this relationship was statistically significant at some stations, and 
Table 3. Seasonal and annual averages $(\mathrm{mm})$ and coefficients of variation in aerodynamic and radiative components of $\mathrm{ET}_{\mathrm{O}}$ at the eight meteorological stations. In bold are the values greater than $50 \%$ of the total $\mathrm{ET}_{\mathrm{O}}$ of the station.

\begin{tabular}{|c|c|c|c|c|c|c|c|c|c|}
\hline & \multicolumn{9}{|c|}{ Aerodynamic } \\
\hline & $\begin{array}{l}\text { Sta. Cruz } \\
\text { de Tenerife }\end{array}$ & $\begin{array}{l}\text { Gran Canaria/ } \\
\text { Airport }\end{array}$ & $\begin{array}{l}\text { Los } \\
\text { Rodeos }\end{array}$ & Izaña & Fuerteventura & La Palma & Lanzarote & $\begin{array}{l}\text { San } \\
\text { Cristóbal }\end{array}$ & Mean \\
\hline & \multicolumn{9}{|c|}{ Average } \\
\hline Winter & 101.6 & 98.8 & 198.8 & 198.8 & 195.9 & 153.2 & 190.4 & 108.1 & 155.7 \\
\hline Spring & 130.5 & 137.5 & 287.2 & 271.0 & 251.1 & 174.3 & 262.0 & 134.7 & 206.0 \\
\hline Summer & 146.2 & 195.6 & 394.7 & 424.7 & 288.5 & 201.7 & 328.1 & 143.1 & 265.3 \\
\hline Autumn & 109.3 & 133.4 & 249.1 & 263.6 & 211.7 & 157.6 & 225.9 & 102.0 & 181.6 \\
\hline \multirow[t]{2}{*}{ Annual } & 487.5 & 568.0 & 1134.4 & 1158.6 & 945.8 & 690.7 & 1004.4 & 485.5 & 809.4 \\
\hline & \multicolumn{9}{|c|}{ Coefficient of variation } \\
\hline Winter & 0.12 & 0.19 & 0.22 & 0.23 & 0.18 & 0.19 & 0.16 & 0.27 & 0.11 \\
\hline Spring & 0.11 & 0.18 & 0.15 & 0.17 & 0.16 & 0.20 & 0.12 & 0.26 & 0.09 \\
\hline Summer & 0.13 & 0.24 & 0.12 & 0.14 & 0.15 & 0.18 & 0.12 & 0.20 & 0.08 \\
\hline Autumn & 0.13 & 0.21 & 0.20 & 0.14 & 0.14 & 0.20 & 0.15 & 0.25 & 0.10 \\
\hline \multirow[t]{4}{*}{ Annual } & 0.09 & 0.16 & 0.13 & 0.12 & 0.14 & 0.16 & 0.11 & 0.17 & 0.07 \\
\hline & \multicolumn{9}{|c|}{ Radiative } \\
\hline & $\begin{array}{l}\text { Sta. Cruz } \\
\text { de Tenerife }\end{array}$ & $\begin{array}{l}\text { Gran Canaria/ } \\
\text { Airport }\end{array}$ & $\begin{array}{l}\text { Los } \\
\text { Rodeos }\end{array}$ & Izaña & Fuerteventura & La Palma & Lanzarote & $\begin{array}{l}\text { San } \\
\text { Cristóbal }\end{array}$ & Average \\
\hline & \multicolumn{9}{|c|}{ Average } \\
\hline Winter & 120.4 & 82.7 & 98.6 & 51.4 & 102.2 & 98.4 & 104.1 & 109.6 & 95.9 \\
\hline Spring & 259.7 & 164.7 & 181.5 & 143.1 & 209.7 & 187.2 & 206.7 & 207.6 & 195.0 \\
\hline Summer & 366.5 & 220.0 & 218.3 & 239.1 & 271.7 & 237.0 & 258.0 & 240.0 & 256.3 \\
\hline Autumn & 202.4 & 140.5 & 152.8 & 100.9 & 172.9 & 158.8 & 167.9 & 176.8 & 159.1 \\
\hline \multirow[t]{2}{*}{ Annual } & 948.1 & 607.0 & 650.0 & 534.0 & 756.3 & 682.0 & 736.7 & 734.0 & 706.0 \\
\hline & \multicolumn{9}{|c|}{ Coefficient of variation } \\
\hline Winter & 0.05 & 0.08 & 0.10 & 0.12 & 0.08 & 0.08 & 0.09 & 0.08 & 0.06 \\
\hline Spring & 0.06 & 0.07 & 0.08 & 0.09 & 0.06 & 0.07 & 0.06 & 0.08 & 0.05 \\
\hline Summer & 0.04 & 0.06 & 0.07 & 0.08 & 0.05 & 0.09 & 0.06 & 0.10 & 0.04 \\
\hline Autumn & 0.05 & 0.05 & 0.08 & 0.07 & 0.05 & 0.06 & 0.06 & 0.06 & 0.04 \\
\hline Annual & 0.03 & 0.04 & 0.07 & 0.06 & 0.04 & 0.05 & 0.04 & 0.06 & 0.03 \\
\hline
\end{tabular}

Table 4. Magnitude of change $\left(\mathrm{mm} \mathrm{decade}^{-1}\right)$ of $\mathrm{ET}_{\mathrm{o}}$ at each meteorological station and the average of the eight stations over the period 1961-2013. Statistically significant differences at the $95 \%$ confidence level are given in bold. Numbers between brackets refer to the magnitudes of change for the periods 1933-2013 for Izaña and 1943-2013 for Santa Cruz de Tenerife.

\begin{tabular}{|c|c|c|c|c|c|c|c|c|c|}
\hline & $\begin{array}{l}\text { Sta. Cruz } \\
\text { de Tenerife }\end{array}$ & $\begin{array}{l}\text { Gran Canaria/ } \\
\text { Airport }\end{array}$ & $\begin{array}{l}\text { Los } \\
\text { Rodeos }\end{array}$ & Izaña & Fuerteventura & La Palma & Lanzarote & $\begin{array}{l}\text { San } \\
\text { Cristóbal }\end{array}$ & Mean \\
\hline Winter & $2.7(0.31)$ & 1.7 & 11.3 & $4.8(-0.42)$ & 3.2 & 9.1 & 7.1 & -5.1 & 4.3 \\
\hline Spring & $0.1(-0.55)$ & 7.7 & 7.1 & $-0.1(-1.27)$ & 3.9 & 7.2 & 4.0 & -5.8 & 3.0 \\
\hline Summer & $1.1(-1.36)$ & 16.0 & 7.6 & $6.0(-0.64)$ & 0.0 & 7.7 & 10.1 & 5.0 & 6.7 \\
\hline Autumn & $\mathbf{2 . 0}(0.62)$ & 3.6 & 11.2 & $3.7(0.30)$ & -0.2 & 9.9 & 4.8 & $-\mathbf{5 . 0}$ & 3.8 \\
\hline Annual & $7.3(-1.95)$ & 28.4 & 34.8 & $14.9(-0.67)$ & 9.2 & 29.8 & 29.7 & -8.4 & 18.2 \\
\hline
\end{tabular}

the correlation coefficients tended to be higher for maximum air temperature. In Los Rodeos and La Palma, the $\mathrm{ET}_{\mathrm{O}}$ variability could not be explained by the variability in air temperature, with correlation coefficients weaker than 0.3. Overall, the results indicate that the seasonal and annual series of $\mathrm{ET}_{\mathrm{o}}$ were significantly correlated with variations in sunshine duration and wind speed, suggesting that these two variables are the key drivers of $\mathrm{ET}_{\mathrm{O}}$ variability in the Canary Islands. 
Table 5. Magnitude of change ( $\mathrm{mm} \mathrm{decade}^{-1}$ ) of both aerodynamic and radiative components of $\mathrm{ET}_{\mathrm{o}}$ at each meteorological station and the average of the eight stations over the period 1961-2013. Statistically significant differences at the $95 \%$ confidence level are given in bold. Numbers between brackets refer to the magnitudes of change for the periods 1933-2013 for Izaña and 1943-2013 for Santa Cruz de Tenerife.

\begin{tabular}{|c|c|c|c|c|c|c|c|c|c|}
\hline & $\begin{array}{l}\text { Sta. Cruz } \\
\text { de Tenerife }\end{array}$ & $\begin{array}{l}\text { Gran Canaria/ } \\
\text { Airport }\end{array}$ & $\begin{array}{l}\text { Los } \\
\text { Rodeos }\end{array}$ & Izaña & Fuerteventura & La Palma & Lanzarote & $\begin{array}{l}\text { San } \\
\text { Cristóbal }\end{array}$ & Mean \\
\hline \multicolumn{10}{|c|}{ Aerodynamic } \\
\hline Winter & $3.7(0.09)$ & 2.9 & 14.8 & $5.1(-0.96)$ & 4.6 & 10.1 & 9.1 & -5.8 & 5.5 \\
\hline Spring & $-1.3(-1.84)$ & 7.8 & 8.9 & $0.1(-3.39)$ & 2.4 & 3.3 & 2.7 & -11.8 & 1.5 \\
\hline Summer & $0.1(-2.95)$ & 16.8 & 9.9 & $6.7(-3.38)$ & -1.1 & 2.5 & 8.1 & -1.5 & 5.2 \\
\hline Autumn & $2.1(-0.51)$ & 5.2 & 14.5 & $3.7(-1.03)$ & -1.1 & 7.9 & 4.6 & -3.8 & 4.1 \\
\hline Annual & $4.7(-6.25)$ & 31.2 & 44.6 & $15.6(-6.93)$ & 6.5 & 19.8 & 28.0 & -21.2 & 16.2 \\
\hline \multicolumn{10}{|c|}{ Radiative } \\
\hline Winter & $-1.0(0.22)$ & -1.2 & -3.5 & $-0.4(0.51)$ & -1.4 & -1.0 & -2.0 & 0.8 & -1.2 \\
\hline Spring & $1.4(1.28)$ & -0.1 & -1.8 & $-0.3(2.12)$ & 1.4 & 3.9 & 1.3 & 6.1 & 1.5 \\
\hline Summer & $1.0(1.58)$ & -0.8 & -2.3 & $-0.7(2.74)$ & 1.1 & 5.1 & 2.0 & 6.5 & 1.5 \\
\hline Autumn & $0.0(1.13)$ & -1.6 & -3.3 & $0.1(1.34)$ & 0.9 & 2.0 & 0.2 & -1.2 & -0.4 \\
\hline Annual & 2.7 (4.29) & -2.8 & -9.9 & $-0.7(6.25)$ & 2.7 & 10.0 & 1.7 & 12.7 & 2.0 \\
\hline
\end{tabular}

Table 6. Seasonal and annual Pearson's coefficients between the evolution of $\mathrm{ET}_{\mathrm{O}}$ and the evolution of aerodynamic and radiative components at the eight meteorological stations and the average. Statistically significant differences at the $95 \%$ confidence level are given in bold.

\begin{tabular}{|c|c|c|c|c|c|c|c|c|c|}
\hline & $\begin{array}{l}\text { Sta. Cruz } \\
\text { de Tenerife }\end{array}$ & $\begin{array}{l}\text { Gran Canaria/ } \\
\text { Airport }\end{array}$ & $\begin{array}{l}\text { Los } \\
\text { Rodeos }\end{array}$ & Izaña & Fuerteventura & La Palma & Lanzarote & $\begin{array}{l}\text { San } \\
\text { Cristóbal }\end{array}$ & Mean \\
\hline \multicolumn{10}{|c|}{ Aerodynamic } \\
\hline Winter & 0.88 & 0.95 & 0.99 & 0.99 & 0.98 & 0.97 & 0.97 & 0.96 & 0.93 \\
\hline Spring & 0.65 & 0.93 & 0.95 & 0.96 & 0.95 & 0.93 & 0.93 & 0.88 & 0.87 \\
\hline Summer & 0.74 & 0.96 & 0.96 & 0.97 & 0.94 & 0.84 & 0.94 & 0.63 & 0.85 \\
\hline Autumn & 0.75 & 0.96 & 0.98 & 0.98 & 0.96 & 0.96 & 0.97 & 0.90 & 0.95 \\
\hline Annual & 0.78 & 0.97 & 0.98 & 0.97 & 0.97 & 0.95 & 0.96 & 0.88 & 0.95 \\
\hline \multicolumn{10}{|c|}{ Radiative } \\
\hline Winter & 0.05 & 0.37 & -0.75 & 0.18 & -0.62 & -0.22 & -0.44 & -0.46 & -0.02 \\
\hline Spring & 0.38 & 0.52 & $-\mathbf{0 . 5 1}$ & 0.36 & -0.25 & 0.14 & 0.07 & -0.17 & 0.28 \\
\hline Summer & 0.05 & 0.28 & -0.37 & -0.62 & -0.12 & 0.23 & 0.08 & 0.41 & 0.29 \\
\hline Autumn & 0.14 & 0.09 & -0.67 & -0.01 & -0.23 & 0.43 & -0.45 & -0.05 & 0.05 \\
\hline Annual & -0.05 & -0.20 & -0.73 & -0.36 & -0.46 & 0.04 & -0.28 & -0.29 & -0.15 \\
\hline
\end{tabular}

The variable that showed the strongest correlation with the evolution of $\mathrm{ET}_{\mathrm{o}}$ in the seasonal and annual series of the different meteorological observatories was relative humidity, with negative coefficients. Only in the annual series of Santa Cruz de Tenerife was the correlation non-significant. Moreover, there were no significant differences in the magnitude of correlations among seasons.

The regional series summarize the pattern observed at the individual meteorological stations (Fig. 7). In winter, relative humidity had the strongest correlation with $\mathrm{ET}_{\mathrm{o}}(r=-0.85)$, with a mostly linear relationship. Minimum air temperature and sunshine duration showed significant positive correlations with $\mathrm{ET}_{\mathrm{o}}$ ( $r=0.40$ and 0.36 , respectively). Maximum air temperature and wind speed showed weaker cor- relation with the winter $\mathrm{ET}_{\mathrm{O}}$. In spring, the magnitude of the correlations was similar among the different variables, and the highest correlation corresponded again to relative humidity $(r=-0.72)$. A similar pattern was found in summer, when relative humidity showed the strongest correlation $(r=-0.74)$ followed by maximum and minimum air temperature. In autumn, relative humidity also showed the strongest correlation and wind speed showed more importance than both maximum and minimum air temperature. As expected, relative humidity showed the strongest correlation with $\mathrm{ET}_{\mathrm{o}}(r=-0.83)$ at the annual scale, followed by wind speed $(r=0.62)$. However, the correlation with maximum air temperature was statistically non-significant. 
Table 7. Seasonal and annual Pearson's coefficients between the time series of $\mathrm{ET}_{\mathrm{O}}$ and the different meteorological variables at the eight meteorological stations, calculated for the period 1961-2013. Statistically significant differences at the $95 \%$ confidence level are given in bold.

\begin{tabular}{|c|c|c|c|c|c|c|c|c|}
\hline & $\begin{array}{l}\text { Sta. Cruz } \\
\text { de Tenerife }\end{array}$ & $\begin{array}{l}\text { Gran Canaria/ } \\
\text { Airport }\end{array}$ & $\begin{array}{l}\text { Los } \\
\text { Rodeos }\end{array}$ & Izaña & Fuerteventura & La Palma & Lanzarote & $\begin{array}{l}\text { San } \\
\text { Cristóbal }\end{array}$ \\
\hline \multicolumn{9}{|c|}{ Maximum air temperature } \\
\hline Winter & 0.32 & 0.51 & -0.12 & 0.89 & -0.23 & -0.01 & -0.23 & 0.26 \\
\hline Spring & 0.46 & 0.69 & 0.02 & 0.90 & 0.18 & 0.01 & 0.62 & 0.42 \\
\hline Summer & 0.48 & 0.80 & 0.10 & 0.18 & 0.33 & 0.27 & 0.51 & 0.44 \\
\hline Autumn & 0.18 & 0.64 & 0.04 & 0.71 & 0.29 & 0.12 & 0.09 & 0.43 \\
\hline Annual & 0.17 & 0.41 & -0.11 & 0.64 & 0.01 & -0.03 & 0.16 & 0.46 \\
\hline \multicolumn{9}{|c|}{ Minimum air temperature } \\
\hline Winter & 0.15 & 0.50 & 0.13 & 0.83 & -0.24 & 0.17 & -0.13 & 0.01 \\
\hline Spring & 0.24 & 0.53 & 0.19 & 0.83 & 0.12 & 0.19 & 0.49 & 0.10 \\
\hline Summer & 0.24 & 0.55 & 0.11 & 0.23 & 0.16 & 0.33 & 0.55 & 0.17 \\
\hline Autumn & 0.21 & 0.56 & 0.36 & 0.63 & 0.20 & 0.32 & 0.26 & 0.21 \\
\hline Annual & 0.04 & 0.47 & 0.13 & 0.54 & -0.11 & 0.30 & 0.27 & -0.07 \\
\hline \multicolumn{9}{|c|}{ Relative humidity } \\
\hline Winter & -0.52 & -0.91 & -0.57 & $-\mathbf{0 . 8 3}$ & -0.92 & -0.92 & -0.89 & -0.72 \\
\hline Spring & -0.34 & -0.89 & -0.70 & -0.90 & -0.89 & -0.90 & -0.77 & -0.82 \\
\hline Summer & -0.35 & -0.93 & -0.83 & -0.46 & -0.90 & -0.89 & $-\mathbf{0 . 8 0}$ & -0.61 \\
\hline Autumn & -0.30 & -0.94 & -0.55 & -0.74 & -0.90 & -0.91 & -0.78 & -0.76 \\
\hline Annual & -0.18 & -0.93 & -0.62 & -0.59 & -0.93 & -0.94 & -0.85 & -0.86 \\
\hline \multicolumn{9}{|c|}{ Sunshine duration } \\
\hline Winter & 0.48 & 0.48 & 0.16 & 0.63 & 0.01 & 0.33 & 0.18 & 0.06 \\
\hline Spring & 0.72 & 0.71 & 0.08 & 0.70 & 0.27 & 0.50 & 0.25 & 0.21 \\
\hline Summer & 0.45 & 0.62 & 0.20 & 0.18 & 0.32 & 0.41 & 0.35 & 0.61 \\
\hline Autumn & 0.47 & 0.38 & 0.20 & 0.53 & 0.14 & 0.69 & 0.16 & 0.34 \\
\hline Annual & 0.40 & 0.30 & -0.01 & 0.40 & 0.15 & 0.48 & 0.08 & -0.09 \\
\hline \multicolumn{9}{|c|}{ Wind speed } \\
\hline Winter & 0.61 & -0.01 & 0.84 & 0.29 & 0.54 & 0.29 & 0.35 & 0.62 \\
\hline Spring & 0.47 & 0.18 & 0.62 & 0.33 & 0.52 & 0.22 & 0.24 & 0.44 \\
\hline Summer & 0.65 & 0.37 & 0.48 & 0.77 & 0.39 & -0.01 & $\mathbf{0 . 3 3}$ & 0.26 \\
\hline Autumn & 0.62 & 0.22 & 0.78 & 0.48 & 0.31 & 0.27 & 0.62 & 0.48 \\
\hline Annual & 0.73 & 0.47 & 0.72 & 0.69 & 0.50 & 0.25 & 0.34 & 0.38 \\
\hline
\end{tabular}

The general increase observed in $\mathrm{ET}_{\mathrm{o}}$ in the Canary Islands was largely determined by changes in the different meteorological variables (Table 8). The maximum air temperature does not show noticeable changes, with the exception of Gran Canaria/Airport, Lanzarote and San Cristóbal stations, where significant trends were found. The regional average did not show significant changes. However, the minimum air temperature showed an average increase of $0.12^{\circ} \mathrm{C}_{\text {decade }}{ }^{-1}$ in summer and $0.09^{\circ} \mathrm{C}$ decade $^{-1}$ at the annual scale between 1961 and 2013. The significant increase recorded in summer was found at six meteorological stations, with a maximum of $0.25^{\circ} \mathrm{C} \mathrm{decade}^{-1}$ in Izaña. Changes in relative humidity were also significant. There was a significant decrease in winter, summer and annually, which represent a decline of $0.47 \%$ decade $^{-1}$, although there were differences among stations. Sunshine duration and wind speed did not show noticeable changes, and the unique remarkable pattern was the significant increase in the summer sunshine duration at the regional scale $\left(0.12 \mathrm{hdecade}^{-1}\right)$ and the significant increase in wind speed at the station of Los Rodeos in the four seasons and also annually.

With respect to the sensitivity of changes in $\mathrm{ET}_{\mathrm{o}}$ to its five driving meteorological drivers (Fig. 8), substantial differences were found between variables. The differences between observed $\mathrm{ET}_{\mathrm{o}}$ and simulated $\mathrm{ET}_{\mathrm{o}}$ with average maximum and minimum air temperature were small irrespective of the season, indicating a low sensitivity to these two variables. In contrast, $\mathrm{ET}_{\mathrm{o}}$ was more sensitive to setting sunshine 
Table 8. Magnitude of change $\left({ }^{\circ} \mathrm{C}, \%\right.$, hours and $\mathrm{ms}^{-1}$ decade $\left.^{-1}\right)$ of the different meteorological variables over the period 1961-2013. In bold are statistically significant trends at the $95 \%$ confidence level.

\begin{tabular}{|c|c|c|c|c|c|c|c|c|c|}
\hline & $\begin{array}{l}\text { Sta. Cruz } \\
\text { de Tenerife }\end{array}$ & $\begin{array}{l}\text { Gran Canaria/ } \\
\text { Airport }\end{array}$ & $\begin{array}{l}\text { Los } \\
\text { Rodeos }\end{array}$ & Izaña & Fuerteventura & La Palma & Lanzarote & $\begin{array}{l}\text { San } \\
\text { Cristóbal }\end{array}$ & Mean \\
\hline \multicolumn{10}{|c|}{ Maximum air temperature } \\
\hline Winter & -0.06 & -0.09 & -0.05 & -0.01 & -0.08 & -0.08 & -0.18 & -0.18 & -0.09 \\
\hline Spring & -0.08 & 0.03 & -0.02 & -0.12 & -0.02 & -0.02 & 0.08 & 0.14 & 0.00 \\
\hline Summer & -0.06 & 0.20 & 0.00 & -0.07 & 0.00 & 0.00 & 0.07 & 0.12 & 0.04 \\
\hline Autumn & -0.06 & -0.08 & -0.08 & -0.04 & -0.10 & -0.06 & -0.11 & -0.17 & -0.09 \\
\hline Annual & -0.05 & 0.03 & -0.01 & -0.05 & -0.03 & -0.02 & -0.01 & 0.00 & -0.02 \\
\hline \multicolumn{10}{|c|}{ Minimum air temperature } \\
\hline Winter & -0.02 & -0.01 & 0.02 & 0.16 & -0.02 & 0.02 & -0.02 & 0.14 & 0.03 \\
\hline Spring & 0.02 & 0.03 & 0.03 & 0.18 & 0.04 & 0.04 & 0.05 & 0.09 & 0.06 \\
\hline Summer & 0.08 & 0.12 & 0.10 & 0.25 & 0.11 & 0.07 & 0.10 & 0.13 & 0.12 \\
\hline Autumn & 0.07 & 0.01 & 0.09 & 0.19 & 0.05 & 0.09 & 0.09 & 0.08 & 0.09 \\
\hline Annual & 0.05 & 0.05 & 0.08 & 0.20 & 0.06 & 0.07 & 0.08 & 0.12 & 0.09 \\
\hline \multicolumn{10}{|c|}{ Relative humidity } \\
\hline Winter & -0.51 & -0.51 & -0.22 & -1.11 & -0.81 & -1.53 & -1.56 & -0.18 & -0.80 \\
\hline Spring & 0.18 & -1.06 & -0.22 & 0.20 & -0.76 & -0.96 & -0.88 & 0.90 & -0.33 \\
\hline Summer & 0.39 & -1.58 & -0.16 & -0.91 & -0.06 & -0.72 & -0.99 & 0.45 & -0.45 \\
\hline Autumn & 0.02 & -0.72 & 0.01 & -0.26 & -0.29 & -1.65 & -0.99 & 0.31 & -0.45 \\
\hline Annual & 0.02 & -0.89 & -0.03 & -0.52 & -0.49 & -1.05 & -1.11 & 0.32 & -0.47 \\
\hline \multicolumn{10}{|c|}{ Sunshine duration } \\
\hline Winter & 0.02 & -0.10 & -0.04 & 0.02 & -0.12 & 0.08 & -0.05 & -0.11 & -0.04 \\
\hline Spring & 0.08 & 0.11 & 0.08 & 0.06 & 0.03 & 0.22 & -0.06 & 0.05 & 0.07 \\
\hline Summer & 0.06 & 0.15 & 0.05 & -0.03 & 0.00 & 0.25 & 0.09 & 0.35 & 0.12 \\
\hline Autumn & 0.03 & -0.04 & 0.03 & 0.08 & 0.00 & 0.19 & 0.03 & -0.16 & 0.02 \\
\hline Annual & 0.06 & 0.03 & 0.03 & 0.04 & -0.01 & 0.18 & 0.02 & 0.04 & 0.05 \\
\hline \multicolumn{10}{|c|}{ Wind speed } \\
\hline Winter & 0.04 & 0.04 & 0.33 & 0.01 & 0.00 & 0.07 & 0.02 & $-\mathbf{0 . 1 8}$ & 0.04 \\
\hline Spring & -0.01 & 0.08 & 0.19 & 0.07 & -0.08 & -0.08 & -0.13 & -0.24 & -0.03 \\
\hline Summer & 0.02 & 0.21 & 0.24 & -0.01 & -0.05 & -0.11 & -0.06 & 0.01 & 0.03 \\
\hline Autumn & 0.03 & 0.07 & 0.33 & 0.03 & -0.07 & -0.05 & -0.04 & -0.06 & 0.03 \\
\hline Annual & 0.02 & 0.10 & 0.27 & 0.02 & -0.04 & -0.04 & -0.04 & -0.12 & 0.02 \\
\hline
\end{tabular}

duration and wind speed at their mean values. Thus, at the station of Los Rodeos, the predicted magnitude of change in winter, autumn and annually was different from the observed magnitude of change. The highest sensitivity was, however, to relative humidity. In general, the different meteorological stations showed an important increase in observed $\mathrm{ET}_{\mathrm{o}}$ with respect to predicted $\mathrm{ET}_{\mathrm{o}}$ keeping relative humidity constant. This was observed at the seasonal and annual scales. Thus, at three meteorological stations the observed magnitude of change on annual basis is between 2 and 3 times higher than that predicted considering relative humidity as stationary. This pattern was also found in the regional series (Fig. 9). Considering air temperature, sunshine duration and wind speed as constant, there were no statistical differences between the observed and predicted magnitudes of change, both seasonally and annually. However, with relative humidity left constant, the magnitude of the trend was quite different to the observations, and temporal trends would not be statistically significant. Thus, the magnitude of change of $\mathrm{ET}_{\mathrm{o}}$, considering relative humidity as constant, is significantly different from the observed magnitude of change in winter and annually.

\section{Discussion}

This work analyses the recent evolution (1961-2013) of reference evapotranspiration $\left(\mathrm{ET}_{\mathrm{o}}\right)$ in the Canary Islands and its relationship with the evolution of its atmospheric drivers. We analysed the time evolution of $\mathrm{ET}_{\mathrm{o}}$ at eight meteoro- 
(a)

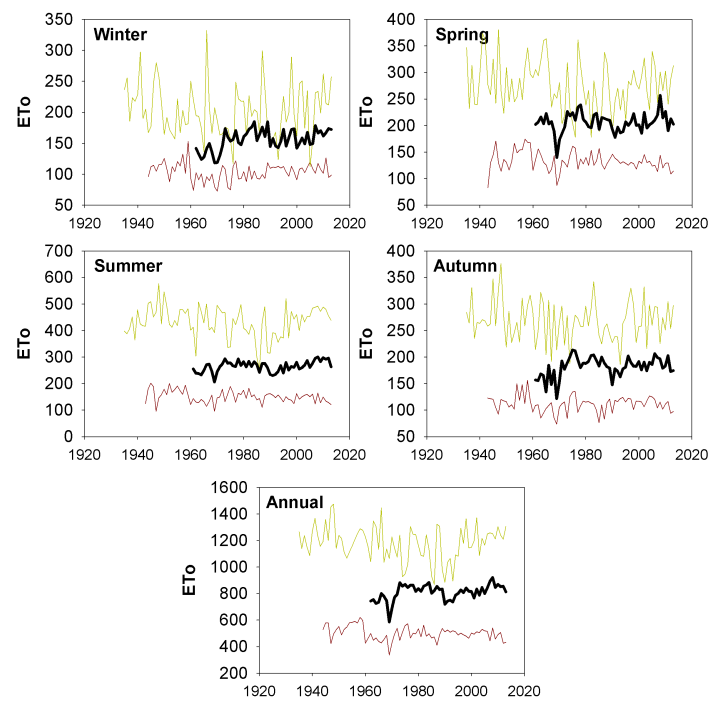

(b)
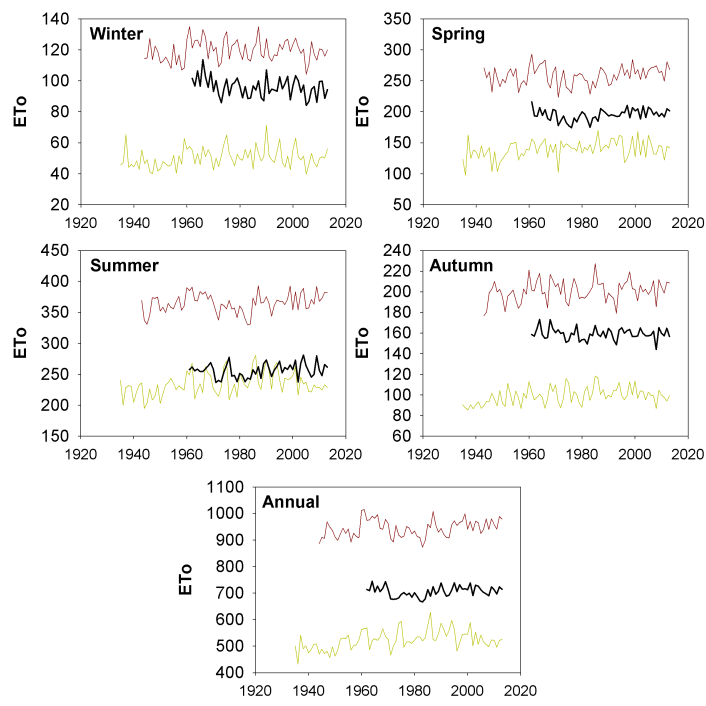

Figure 6. Evolution of seasonal and annual aerodynamic (a) and radiative (b) components of the $\mathrm{ET}_{\mathrm{O}}$ at the two meteorological stations with longest records (Izaña, green, and Santa Cruz de Tenerife, brown) and the average of the eight stations (black lines) from 1961 to 2013.

logical stations in which the necessary meteorological variables for calculation of the $\mathrm{ET}_{\mathrm{o}}$ were available. The results showed a general increase in $\mathrm{ET}_{\mathrm{o}}$, although different magnitudes of change were found between the different meteorological stations. These differences did not follow any specific geographic pattern, so they must be considered to be due to either random effects and uncertainty at various levels or micro-geographic effects that were not considered in this study. There is no general pattern that may connect the observed trends in a certain forcing variable with the observed trend of $\mathrm{ET}_{\mathrm{O}}$ at each of the eight analysed stations, although those that showed a higher increase in $\mathrm{ET}_{\mathrm{o}}$ (i.e. Lanzarote, Los Rodeos and Gran Canaria) displayed a higher increase in the aerodynamic component, a process which is in agreement with the significant reductions observed in relative humidity.

Nevertheless, with the exception of the observatory of San Cristóbal in the north of Gran Canaria, other meteorological observatories showed positive changes in $\mathrm{ET}_{\mathrm{o}}$, with annual trends statistically significant at six stations. In any case, we must also stress that trends in $\mathrm{ET}_{\mathrm{o}}$ at the regional scale are mostly significant because of the low values in the beginning of the study period starting in the 1960s. Thus, the results of the two sites with longer temporal coverage (i.e. Izaña and Santa Cruz de Tenerife) do not show significant trends. This makes necessary to consider these trends with caution since they could be driven by variability processes at the decadal scale.

The few existing studies in northwestern Africa (Ouysse et al., 2010; Tekken and Kropp, 2012) are not comparable with our findings, since the variables required to apply the PM equation were not available. Instead, these studies relied on simplified methods that just employ air temperature records. Despite the difference in methods, these studies also found a general increase in the $\mathrm{ET}_{\mathrm{O}}$. The closest region in which it is possible to make a direct comparison using the same method is the Iberian Peninsula, where a general increase of $24.5 \mathrm{~mm} \mathrm{decade}^{-1}$ was found between 1961 and 2011 (Vicente-Serrano et al., 2014a). This study also found that the variability and trends in the aerodynamic component determined most of the observed variability and the magnitude of change of $\mathrm{ET}_{\mathrm{o}}$ at the majority of the meteorological stations in the Iberian Peninsula. The radiative component showed much lower temporal variability than the aerodynamic component did. Thus, more than $90 \%$ of the observed $\mathrm{ET}_{\mathrm{o}}$ variability at the seasonal and annual scales can be associated with the variability in the aerodynamic component. This is in agreement with the results obtained in previous studies. For example, Wang et al. (2012) showed that recent $\mathrm{ET}_{\mathrm{o}}$ variability at the global scale was mainly driven by the aerodynamic component. Equally, other studies in southern Europe indicated a higher importance of the aerodynamic component (Sanchez-Lorenzo et al., 2014; Azorin-Molina et al., 2015). It could be argued, however, that quantification of the radiative component in our study was based on a simplified assumption since it was calculated from sunshine duration, which is mostly determined by cloud coverage (Hoyt, 1978). Nevertheless, it is also worth noting that global radiation measurements and sunshine duration records contain a signal of the direct effects of aerosols (Sanroma et al., 2010; Sanchez-Romero et al., 2014; Wild, 2015) in the Canary Islands. Nevertheless, the Canary Islands is a region mostly free of anthropogenic aerosols given the large frequency and intensity of trade winds (Mazorra et al., 2007), and it is not expected that the frequency of Saharan dust events, which 

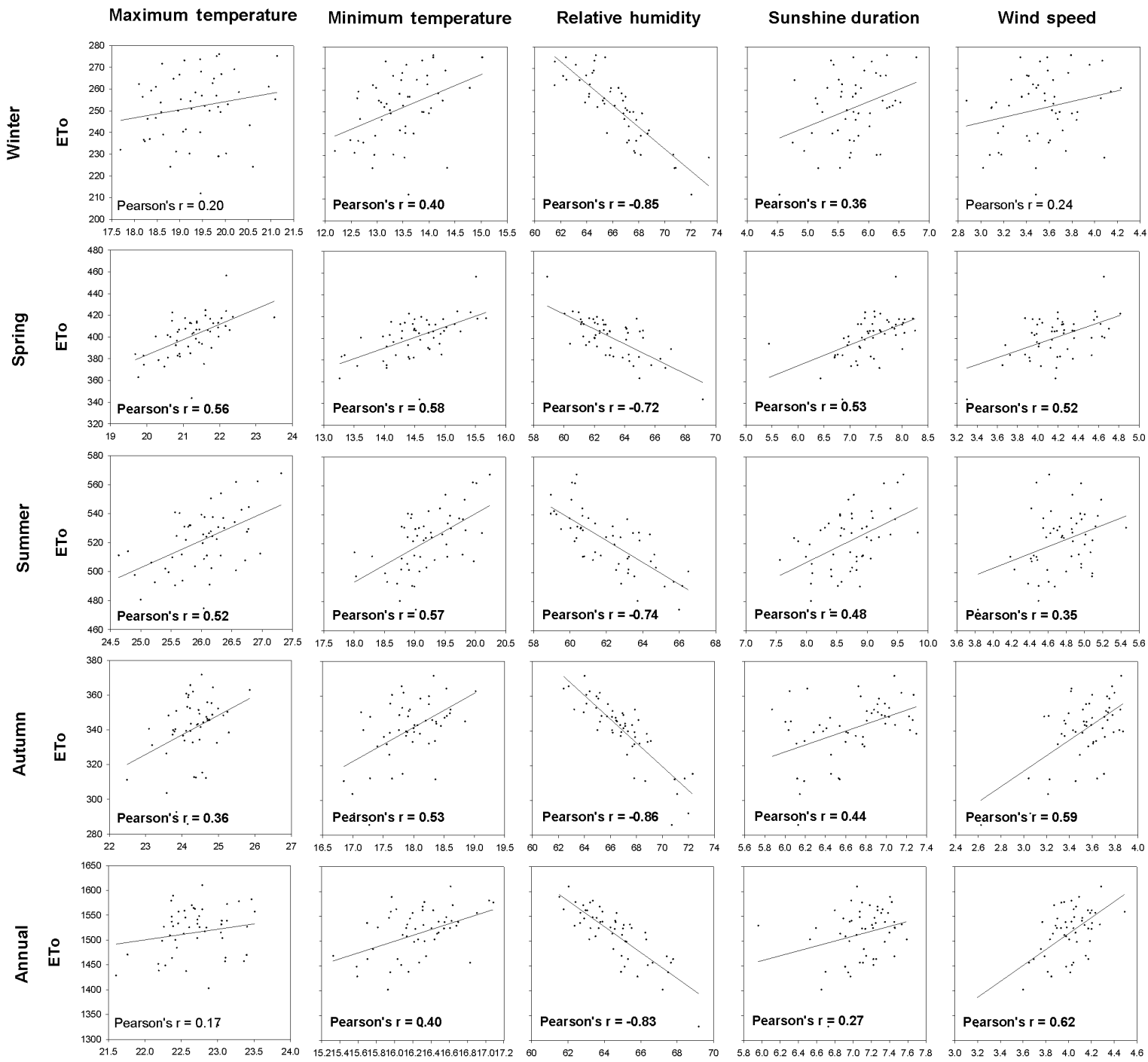

${ }^{\circ} \mathrm{C}$

${ }^{\circ} \mathrm{C}$

$\%$

h

$\mathrm{m} \mathrm{s}^{-1}$

Figure 7. Relationship between the regional annual and seasonal $\mathrm{ET}_{\mathrm{o}}$ and the regional series of the different meteorological variables. Pearson's coefficients are included in each plot. In bold are the coefficients that statistically significant at the $95 \%$ confidence level.

could affect incoming solar radiation, has noticeably changed over the last decades (Flentje et al., 2015; Laken et al., 2015). Consequently, in the Canary Islands we can consider high accuracy in determining the radiative component using sunshine duration series. In continental Spain, Azorin-Molina et al. (2015) also found strong positive correlations between interannual variations in solar radiation and sunshine duration at different meteorological stations. Overall, in the Canary Islands there is a positive and significant correlation between interannual variations in $\mathrm{ET}_{\mathrm{O}}$ and sunshine duration, although this correlation did not explain the observed trends of $\mathrm{ET}_{\mathrm{O}}$ in the region.

We showed that the temporal variability in $\mathrm{ET}_{\mathrm{o}}$ is strongly controlled by the temporal variability in relative humidity. Specifically, seasonal and annual series of $\mathrm{ET}_{\mathrm{O}}$ at the differ- ent stations showed very strong negative and significant correlations with those of the relative humidity. Thus, the magnitude of correlations was much higher than those obtained for other meteorological variables, and this finding was common to the whole set of meteorological stations. This strong control of relative humidity on the temporal variability in $\mathrm{ET}_{\mathrm{o}}$ has been already identified in some studies in the Iberian Peninsula (Vicente-Serrano et al., 2014b; Azorin-Molina et al., 2015; Espadafor et al., 2013).

Among the variables that control the aerodynamic component, wind speed and maximum air temperature did not show significant trends at the regional scale, and only a few stations recorded significant trends in these variables at either the seasonal or the annual scale. Significant trends were obtained for minimum air temperature, mainly in summer. Recently, 

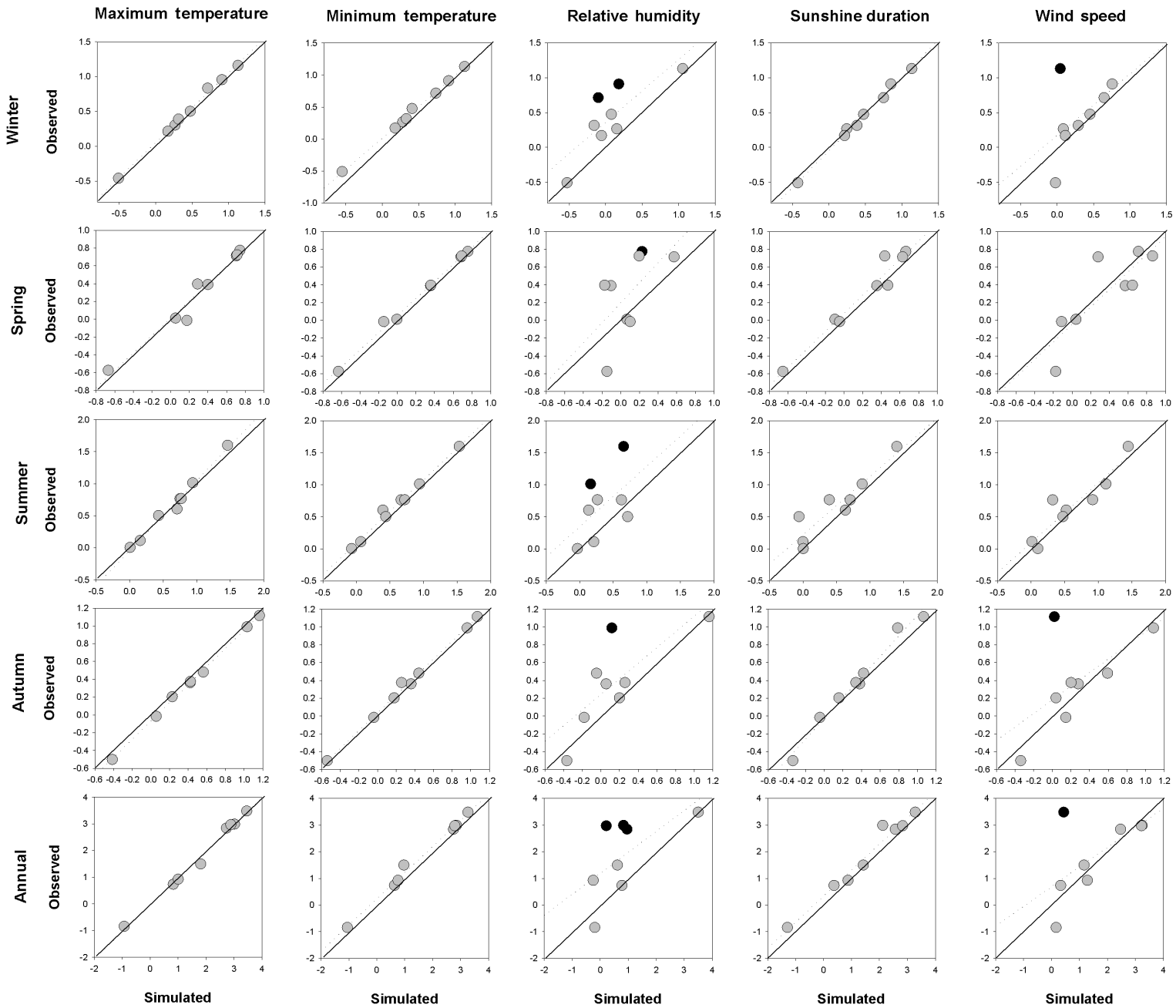

Figure 8. Relationship between the observed change in $\mathrm{ET}_{\mathrm{O}}$ (mm year-1) at each meteorological station and the change in simulated $\mathrm{ET}_{\mathrm{O}}$ considering each one of the meteorological variables used to calculate $\mathrm{ET}_{\mathrm{O}}$ as constant for the period 1961-2013. Black dots indicate significant differences in the trends.

Cropper and Hanna (2014) analysed long-term climate trends in the Macaronesia region, and for the Canary Islands they showed an increase in air temperature during summer for the period 1981-2010. Martín et al. (2012) analysed air temperature changes in Tenerife from 1944 to 2010, and they also showed that night-time air temperature increased rapidly compared to daytime temperature. Nevertheless, they found strong spatial contrasts between the high mountains, which showed a higher increase, and the coastal areas in which the air temperature regulation of the ocean could be reducing the general air temperature increase.

In any case, the variable that recorded more significant changes in the Canary Islands was relative humidity, and among the different meteorological variables used to calculate $\mathrm{ET}_{\mathrm{o}}$, relative humidity was the main driver of the observed $\mathrm{ET}_{\mathrm{o}}$ trends. Significant negative humidity trends were recorded in winter, summer and autumn, but also annually.
Thus, simulation of $\mathrm{ET}_{\mathrm{o}}$ series considering the different meteorological variables as constant produced few differences in relation to the observed evolution of $\mathrm{ET}_{\mathrm{o}}$, with the exception of the relative humidity. Leaving relative humidity as constant for the period 1961-2013 showed no significant $\mathrm{ET}_{\mathrm{o}}$ changes at seasonal and annual scales and also statistically significant differences with changes obtained from observations. In continental Spain, Vicente-Serrano et al. (2014b) showed a general decrease in relative humidity from the decade of 1960, mainly associated with a general decrease in the moisture transport to the Iberian Peninsula as well as a certain precipitation decrease. Similarly, Espadafor et al. (2011) and Vicente-Serrano et al. (2014b) showed that the strong increase in $\mathrm{ET}_{\mathrm{O}}$ in the last decades is associated with the relative humidity decrease due to air temperature rise, which caused more severe drought events (Coll et al., 2016; Lorenzo-Lacruz and Morán-Tejeda, 2016; Peña- 

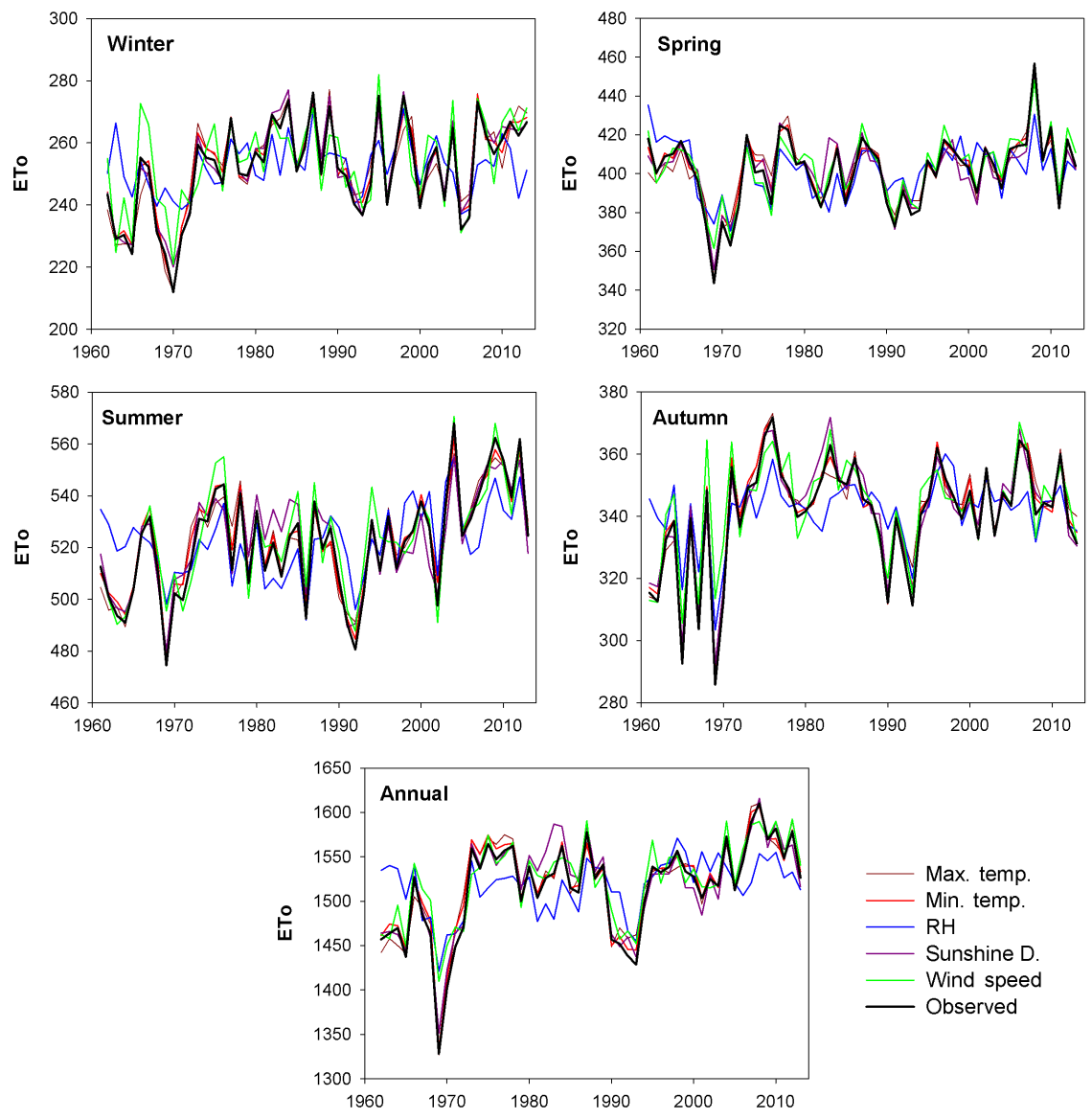

Figure 9. Seasonal and annual evolution of the observed regional $\mathrm{ET}_{\mathrm{O}}$ compared to the evolution of simulated $\mathrm{ET}_{\mathrm{O}}$ considering each one of the meteorological variables used to calculate $\mathrm{ET}_{\mathrm{O}}$ as constant for the period 1961-2013.

Gallardo et al., 2016). In the Canary Islands, no precipitation changes have been identified during the analysed period (Sánchez-Benitez et al., 2016). Therefore a lower moisture supply from the humidity sources to the islands should explain the observed pattern toward a relative humidity decrease. Sherwood and $\mathrm{Fu}$ (2014) suggested that differences in the air temperature increase between oceanic and continental areas could increase land aridity, as a consequence of the subsaturation conditions of the oceanic air masses that come to the land areas, given higher warming rates in maritime regions in comparison to continental areas. The results of this study confirm this pattern in the Canary Islands, since this region should not be constrained by constant moisture supply from the surrounding warm Atlantic Ocean. Overall, Willett et al. (2014) recently found a general decrease in relative humidity at the global scale, including several islands and coastal regions in which the moisture supply was expected to be unlimited. This finding suggests that contrasted mean air temperature and trends between land and ocean areas could also play an important role in explaining this phenomenon, even at local scales.

\section{Conclusions}

We found that the reference evapotranspiration $\mathrm{ET}_{\mathrm{o}}$ increased by $18.2 \mathrm{~mm}_{\text {decade }}{ }^{-1}$ - on average - between 1961 and 2013 over the Canary Islands, with the highest increase recorded during summer.

Although there were noticeable spatial differences, this increase was mainly driven by changes in the aerodynamic component, caused by a statistically significant reduction of the relative humidity.

This study provides an outstanding example of how climate change and interactions between different meteorological variables drive an increase in the $\mathrm{ET}_{\mathrm{o}}$ event in a subtropical North Atlantic archipelago. Given the general aridity conditions in most of the Canary Islands and the scarcity of water resources, the observed trend could have negative consequences in a number of water-depending sectors if it continues in the future. 


\section{Data availability}

Data used here are licensed by the Spanish National Meteorological Agency (AEMet) and cannot be redistributed. Potential users of the raw data can directly contact AEMet (http://www.aemet.es/).

Acknowledgements. The authors thank the Spanish Meteorological Agency (AEMET) for providing the climate data used in this study. This work was supported by the research projects PCIN-2015-220, CGL2014-52135-C03-01, and Red de variabilidad y cambio climático RECLIM (CGL2014-517221-REDT), financed by the Spanish Commission of Science and Technology and FEDER; "IMDROFLOOD-Improved Drought and Flood Early Warning, Forecasting and Mitigation using real-time hydroclimatic indicators", supported through the Water Joint programme Initiative "Water Challenges for a Changing World"; and Water Works 2014 Cofunded call and "LIFE12 ENV/ES/000536-Demonstration and validation of innovative methodology for regional climate change adaptation in the Mediterranean area (LIFE MEDACC)", financed by the LIFE programme of the European Commission. Cesar Azorin-Molina (JCI-2011-10263), Arturo Sanchez-Lorenzo (JCI-2012-12508) and Marina Peña-Gallardo received grants from the Spanish Ministry of Economy and Competitiveness; Natalia Martin-Hernandez was supported by a doctoral grant by the Aragón Regional Government; and Miquel Tomas-Burguera was supported by a doctoral grant by the Ministerio de Educación, Cultura y Deporte.

Edited by: L. Pfister

Reviewed by: two anonymous referees

\section{References}

Abtew, W., Obeysekera, J., and Iricanin, N.: Pan evaporation and potential evapotranspiration trends in South Florida, Hydrol. Process. 25, 958-969, 2011.

Allen, R. G. Pereira, L. S., Raes, D., and Smith, M.: Crop evapotranspiration: Guidelines for computing crop water requirements, Food and Agricultural Organization (FAO), Irrig. Drain. pap. 56, Rome, 1998.

Allen, C. D., Breshears, D., and McDowell, N. G.: On underestimation of global vulnerability to tree mortality and forest die-off from hotter drought in the Anthropocene, Ecosphere, 6, 1-55, 2015.

Ambas, V. T. and Baltas, E.: Sensitivity analysis of different evapotranspiration methods using a new sensitivity coefficient, Global Nest J., 14, 335-343, 2012.

Azorin-Molina, C., Vicente-Serrano, S. M., Sanchez-Lorenzo, A., McVicar, T. R., Morán-Tejeda, E., Revuelto, J., El Kenawy, A., Martín-Hernández, N., and Tomas-Burguera, M.: Atmospheric evaporative demand observations, estimates and driving factors in Spain (1961-2011), J. Hydrol., 523, 262-277, 2015.

Chaouche, K., Neppel, L., Dieulin, C., Pujol, N., Ladouche, B., Martin, E., Salas, D., and Caballero, Y.: Analyses of precipitation, temperature and evapotranspiration in a French Mediter- ranean region in the context of climate change, C. R. Geosci., 342, 234-243, 2010.

Coll, J. R., Aguilar, E., Prohom, M., and Sigró, J.: Long-term drought variability and trends in Barcelona (1787-2014), Cuad. Invest. Geogr., 42, doi:10.18172/cig.2927, 2016.

Cropper, T. E. and Hanna, E.: An analysis of the climate of Macaronesia, 1865-2012, Int. J. Climatol., 34, 604-622, 2014.

Custodio, E. and Cabrera, M. C.: Cómo convivir con la escasez de agua? El caso de las Islas Canarias, Boletin Geologico y Minero, 113, 243-258, 2002.

Dai, A.: Increasing drought under global warming in observations and models, Nature Clim. Change, 3, 52-58, 2013.

Darshana, A., Pandey, R., and Pandey, P.: Analysing trends in reference evapotranspiration and weather variables in the Tons River Basin in Central India, Stoch. Environ. Res. Risk A, doi:10.1007/s00477-012-0677-7, 2012.

El Kenawy, A. and McCabe, M. F.: A multi-decadal assessment of the performance of gauge- and model-based rainfall products over Saudi Arabia: climatology, anomalies and trends, Int. J. Climatol., doi:10.1002/joc.4374, 2015.

Espadafor, M., Lorite, I. J., Gavilán, P., and Berengena, J.: An analysis of the tendency of reference evapotranspiration estimates and other climate variables during the last 45 years in Southern Spain, Agric. Water Manag., 98, 1045-1061, 2011.

Fan, Z.-X. and Thomas, A.: Spatiotemporal variability of reference evapotranspiration and its contributing climatic factors in Yunnan Province, SW China, 1961-2004, Clim. Change, 116, 309-325, 2013.

Flentje, H., Briel, B., Beck, C. et al.: Identification and monitoring of Saharan dust: An inventory representative for south Germany since 1997, Atmos. Environ., 109, 87-96, 2015.

García, R. D., Cuevas, E., García, O. E., Cachorro, V. E., Pallé, P., Bustos, J. J., Romero-Campos, P. M., and de Frutos, A. M.: Reconstruction of global solar radiation time series from 1933 to 2013 at the Izaña Atmospheric Observatory, Atmos. Meas. Tech., 7, 3139-3150, doi:10.5194/amt-7-3139-2014, 2014.

Hamed, K. H. and Rao, A. R.: A modified Mann Kendall trend test for autocorrelated data, J. Hydrol., 204, 182-196, 1998.

Hargreaves, G. L. and Samani, Z. A.: Reference crop evapotranspiration from temperature, Appl. Eng. Agric. 1, 96-99, 1985.

Hoyt, D. V.: Interannual Cloud-Cover Variations in the Contiguous United States, J. Appl. Meteor., 17, 354-357, 1978.

Huntington, T. G.: Evidence for intensification of the global water cycle: Review and synthesis, J. Hydrol., 319, 83-95, 2006.

Itenfisu, D., Elliott, R. L., Allen, R. G., and Walter, I. A.: Comparison of Reference Evapotranspiration Calculations across a Range of Climates, Proceedings of the 4th National Irrigation Symposium, ASAE, Phoenix, AZ, 2000.

Jhajharia, D., Kumar, R., Dabral, P. P., Singh, V. P., Choudhary, R. R., and Dinpashoh, Y.: Reference evapotranspiration under changing climate over the Thar Desert in India, Met. Apps, 22, 425-435, doi:10.1002/met.1471, 2015.

Kousari, M. R. and Ahani, H.: An investigation on reference crop evapotranspiration trend from 1975 to 2005 in Iran, Int. J. Climatol. 32, 2387-2402, 2012.

Laken, B. A., Parviainen, H., García-Gil, A., Muñoz-Tuñón, C., Varela, A. M., Fernandez-Acosta, S., and Pallé, P.: Thirty years of atmospheric extinction from telescopes of the North Atlantic Ca- 
nary Archipelago, J. Climate, doi:10.1175/JCLI-D-14-00600.1, 2015.

Liu, T., Li, L., Lai, J., Liu, C., and Zhuang, W.: Reference evapotranspiration change and its sensitivity to climate variables in southwest China, Theor. Appl. Climatol., in press, 2015.

López-Urrea, R., Martín de Santa Olalla, F., Fabeiro, C., and Moratalla, A.: Testing evapotranspiration equations using lysimeter observations in a semiarid climate, Agric. Water Manage., 85, 15-26, 2006.

Lorenzo-Lacruz, J. and Morán-Tejeda, E.: Spatio-temporal patterns of meteorological droughts in the Balearic Islands (Spain), Cuad. Invest. Geogr., 42, 29-48, doi:10.18172/cig.2948, 2016.

Ma, X., Zhang, M., Li, Y., Wang, S., Ma, Q., and Liu, W.: Decreasing potential evapotranspiration in the Huanghe River Watershed in climate warming during 1960-2010, J. Geogr. Sci., 22, 977988, 2012

Martín, J. L., Bethencourt, J., and Cuevas-Agulló, E.: Assessment of global warming on the island of Tenerife, Canary Islands (Spain). Trends in minimum, maximum and mean temperatures since 1944, Clim. Change, 114, 343-355, 2012.

Matsoukas, C., Benas, N., Hatzianastassiou, N., Pavlakis, K. G., Kanakidou, M., and Vardavas, I.: Potential evaporation trends over land between 1983-2008: driven by radiative fluxes or vapour-pressure deficit?, Atmos. Chem. Phys., 11, 7601-7616, doi:10.5194/acp-11-7601-2011, 2011.

Mazorra, L., Diaz, F., Navarro, P., and Deniz, F.: Accumulated frequency estimation for daily clearness index, ISES Solar World Congress 2007, ISES 20074, 2632-2635, 2007.

Mestre, O., Domonkos, P., Picard, F., Auer, I., Robin, S., Lebarbier, E., Böhm, R., Aguilar, E., Guijarro, J., Vertacnik, G., Klancar, M., Dubuisson, B., and Stepanek, P.: HOMER: HOMogenisation softwarE in R-methods and applications, Idöjárás, 117, 47-67, 2013.

McMahon, T. A., Peel, M. C., Lowe, L., Srikanthan, R., and McVicar, T. R.: Estimating actual, potential, reference crop and pan evaporation using standard meteorological data: a pragmatic synthesis, Hydrol. Earth Syst. Sci., 17, 1331-1363, doi:10.5194/hess-17-1331-2013, 2013.

McVicar, T. R., Roderick, M. L., Donohue, R. J., and Van Niel, T. G.: Less bluster ahead? ecohydrological implications of global trends of terrestrial near-surface wind speeds, Ecohydrology, 5, 381-388, 2012a.

McVicar, T. R., Roderick, M. L., Donohue, R. J., Li, L. T., Van Niel, T. G., Thomas, A., Grieser, J., Jhajharia, D., Himri, Y., Mahowald, N. M., Kruger, A. C., Rehman, S., and Dinpashoh, Y.: Global review and synthesis of trends in observed terrestrial near-surface wind speeds: implications for evaporation, J. Hydrol., 416-417, 182-205, 2012b.

Ouysse, S., Laftouhi, N.-E., and Tajeddine, K.: Evaluation of evapotranspiration variation in the Draa basin using statistical and empirical methods (South-Eastern Morocco), XXXVIIIIAH Congress Groundwater Quality Sustainability, Krakow, 12-17 September 2010, 2010.

Paternoster, R., Brame, R., Mazerolle, P., and Piquero, A. R.: Using the Correct Statistical Test for the Equality of Regression Coefficients, Criminology, 36, 859-866, 1998.

Peña-Gallardo, M., Gámiz-Fortis, S. R., Castro-Díez, Y., and Esteban-Parra, M. J.: Análisis comparativo de índices de sequía en Andalucía para el periodo 1901-2012, Cuad. Invest. Geogr., 42, 67-88, doi:10.18172/cig.2946, 2016.

Peterson, T. C., Golubev, V. S., and Groisman, P. Y.: Evaporation losing its strength, Nature, 377, 687-688, 1995.

Piticar, A., Mihăilă, D., Lazurca, L. G., Bistricean, P.-I., Putuntică, A., and Briciu, A.-E.: Spatiotemporal distribution of reference evapotranspiration in the Republic of Moldova, Theor. Appl. Climatol., in press, 2015.

Roderick, M. L. and Farquhar, G. D.: The cause of decreased pan evaporation over the past 50 years, Science, 298, 1410-1411, 2002.

Roderick, M. L. and Farquhar, G. D.: Changes in Australian pan evaporation from 1970 to 2002, Int. J. Climatol., 24, 1077-1090, 2004.

Sánchez-Benítez, A., García-Herrera, R., and Vicente-Serrano, S. M.: Revisiting precipitation variability, trends and drivers in the Canary Islands, submitted to Int. J. Climatol., 2016.

Sanchez-Lorenzo, A., Vicente-Serrano, S. M., Wild, M., Calbó, J., Azorin-Molina, C., and Peñuelas, J.: Evaporation trends in Spain: a comparison of Class A pan and Piché atmometer measurements, Clim. Res., 61, 269-280, 2014.

Sanchez-Romero, A., Sanchez-Lorenzo, A., Calbó, J., González, J. A., and Azorin Molina, C.: The signal of aerosolinduced changes in sunshine durationrecords: A review of the evidence, J. Geophys. Res. Atmos., 119, 4657-4673, doi:10.1002/2013JD021393, 2014.

Sanroma, E., Palle, E., and Sanchez-Lorenzo, A.: Long-term changes in insolation and temperatures at different altitudes, Environ. Res. Lett., 5, 6 pp., 2010.

Sheffield, J., Wood, E. J., and Roderick, M. L.: Little change in global drought over the past 60 years, Nature, 491, 435-438, 2012.

Sherwood, S. and Fu, Q.: A drier future?, Science, 343, 737-739, 2014.

Tabari, H., Nikbakht, J., and Talaee, P. H.: Identification of trend in reference evapotranspiration series with serial dependence in Iran, Water Resour. Manag., 26, 2219-2232, 2012.

Tekken, V. and Kropp, J. P.: Climate-driven or human-induced: Indicating severe water scarcity in the Moulouya river basin (Morocco), Water, 4, 959-982, 2012.

Thornthwaite, C. W.: An approach toward a rational classification of climate, Geogr. Rev., 38, 55-94, 1948.

Venema, V. K. C., Mestre, O., Aguilar, E., Auer, I., Guijarro, J. A., Domonkos, P., Vertacnik, G., Szentimrey, T., Stepanek, P., Zahradnicek, P., Viarre, J., Müller-Westermeier, G., Lakatos, M., Williams, C. N., Menne, M. J., Lindau, R., Rasol, D., Rustemeier, E., Kolokythas, K., Marinova, T., Andresen, L., Acquaotta, F., Fratianni, S., Cheval, S., Klancar, M., Brunetti, M., Gruber, C., Prohom Duran, M., Likso, T., Esteban, P., and Brandsma, T.: Benchmarking homogenization algorithms for monthly data, Clim. Past, 8, 89-115, doi:10.5194/cp-8-89-2012, 2012.

Vicente-Serrano, S. M., Beguería, S., López-Moreno, J. I., GarcíaVera, M. A., and Stepanek, P.: A complete daily precipitation database for North-East Spain: reconstruction, quality control and homogeneity, Int. J. Climatol., 30, 1146-1163, 2010.

Vicente-Serrano, S. M., Azorin-Molina, C., Sanchez-Lorenzo, A., Revuelto, J., López-Moreno, J. I., González-Hidalgo, J. C., and Espejo, F.: Reference evapotranspiration variability and trends in Spain, 1961-2011, Global Planet. Change, 121, 26-40, 2014 a. 
Vicente-Serrano, S. M., Azorin-Molina, C., Sanchez-Lorenzo, A., Morán-Tejeda, E., Lorenzo-Lacruz, J., Revuelto, J., LópezMoreno, J. I., and Espejo, F.: Temporal evolution of surface humidity in Spain: recent trends and possible physical mechanisms, Clim. Dynam., 42, 2655-2674, 2014 b.

Wang, K. and Dickinson, R. E.: A review of global terrestrial evapotranspiration: observation, modeling, climatology, and climatic variability, Rev. Geophys., 50, RG2005, doi:10.1029/2011RG000373, 2012.

Wang, K., Dickinson, R. E., and Liang, S.: Global atmospheric evaporative demand over land from 1973 to 2008, J. Clim., 25, 8353-8361, 2012.

Wild, M.: Decadal changes in radiative fluxes at land and ocean surfaces and their relevance for global warming, WIREs, Clim. Change, 7, 91-107, doi:10.1002/wcc.372, 2015.

Willett, K. M., Dunn, R. J. H., Thorne, P. W., Bell, S., de Podesta, M., Parker, D. E., Jones, P. D., and Williams Jr., C. N.: HadISDH land surface multi-variable humidity and temperature record for climate monitoring, Clim. Past, 10, 1983-2006, doi:10.5194/cp10-1983-2014, 2014.
Xu, H.-Y., Gong, L., Jiang, T., Chen, D., and Singh, V. P.: Analysis of spatial distribution and temporal trend of reference evapotranspiration and pan evaporation in Changjiang (Yangtze River) catchment, J. Hydrol., 327, 81-93, 2006.

Yue, S. and Wang, C.: The Mann-Kendall Test Modified by Effective Sample Size to Detect Trend in Serially Correlated Hydrological Series, Water Resour. Manage., 18, 201-218, 2004.

Zhang, X., Harvey, K. D., Hogg, W. D., and Yuzyk, T. R.: Trends in Canadian streamflow, Water Resour. Res., 37, 987-998, 2001.

Zhang, Y., Liu, C., Tang, Y., and Yang, Y.: Trends in pan evaporation and reference and actual evapotranspiration across the Tibetan Plateau, J. Geophys. Res.-Atmos. 112, D12110, doi:10.1029/2006JD008161, 2007. 